\title{
How local is local? Evidence from bank competition and corporate innovation in U.S.
}

Article

Accepted Version

Tian, L. and Han, L. (2019) How local is local? Evidence from bank competition and corporate innovation in U.S. Review of Quantitative Finance and Accounting, 52 (1). pp. 289-324. ISSN 1573-7179 doi: https://doi.org/10.1007/s11156-0180710-0 Available at https://centaur.reading.ac.uk/75641/

It is advisable to refer to the publisher's version if you intend to cite from the work. See Guidance on citing.

To link to this article DOI: http://dx.doi.org/10.1007/s11156-018-0710-0

Publisher: Springer

All outputs in CentAUR are protected by Intellectual Property Rights law, including copyright law. Copyright and IPR is retained by the creators or other copyright holders. Terms and conditions for use of this material are defined in the End User Agreement.

$\underline{\text { www.reading.ac.uk/centaur }}$

\section{CentAUR}


Central Archive at the University of Reading

Reading's research outputs online 


\section{How local is local? Evidence from bank competition and corporate innovation in U.S.}

Article

Accepted Version

Tian, L. and Han, L. (2018) How local is local? Evidence from bank competition and corporate innovation in U.S. Review of Quantitative Finance and Accounting. ISSN 1573-7179 (In Press) Available at http://centaur.reading.ac.uk/75422/

It is advisable to refer to the publisher's version if you intend to cite from the work.

Publisher: Springer

All outputs in CentAUR are protected by Intellectual Property Rights law, including copyright law. Copyright and IPR is retained by the creators or other copyright holders. Terms and conditions for use of this material are defined in the End User Agreement.

www.reading.ac.uk/centaur 
Central Archive at the University of Reading

Reading's research outputs online 


\title{
How local is local? Evidence from bank competition and corporate innovation in U.S.
}

\author{
Lin $\operatorname{Tian}^{1} \cdot$ Liang Han ${ }^{2}$
}

\begin{abstract}
This paper aims to fill in a research gap in the effects of bank competition on corporate innovation. In addition to the evidence on the favorable effects of bank competition on corporate innovation, this paper shows novel evidence on the substitution effects of bank competition in a wider region and neighbor-state to local bank competition in financing corporate innovation activities. In financing innovation, we show 'how local is local' depends on the operating scope and information transparency of firms. Local banks have an information advantage over distant banks in financing local businesses and informationally opaque corporate innovation activities. Therefore, improved competition in distant banking markets may have limited ability to substitute the favorable effects of local bank competition in facilitating corporate innovation activities.
\end{abstract}

Keywords Bank competition · Corporate innovation - Substitution · Operating scope · Information transparency

JEL Classification $\mathrm{G} 10 \cdot \mathrm{G} 20 \cdot \mathrm{G} 21$

Acknowledgement We thank Manthos Delis, Mauro Costantini, Dimitris Petmezas, Fu Xin, the participants of European Financial Management Symposium, Editor-in-Chief Prof Cheng-Few Lee, and two anonymous referees for helpful comments and suggestions to this study.

Lin Tian

$\underline{\text { Lin.Tian@uestc.edu.cn }}$

Liang Han

Liang.Han@henley.ac.uk

${ }^{1}$ School of Management and Economics, University of Electronic Science and Technology of China, Chengdu, 610054, China

${ }^{2}$ Henley Business School, University of Reading, Reading, RG6 6UD, U.K 


\section{Introduction}

Given the substantial changes in banking markets after liberalization and deregulation, existing literature has identified various correlations among the structures in a setting of cross-regional banking markets (e.g. Richards et al. 2008; Michalski and Ors 2012) and the effects of improved bank competition on businesses, such as the cost of finance (Rice and Strahan 2010) and corporate innovation (Amore et al. 2013). What is little known, however, is how such a cross-regional bank competition since deregulation has contributed to corporate finance. With the removal of interstate bank entry barriers since 1990s, the U.S. banking market has become more competitive. The entry of out-of-state banks (Rice and Strahan 2010) and the increasing borrower-lender distance (Petersen and Rajan 2002) have been found to affect credit conditions in alreadycompetitive urban areas, making local banks exposed to a greater competition from those banks locating in both local and distant markets and to restrict their lending to more proximate borrowers due to an information advantage (Dell'Ariccia and Marquez 2004; Hauswald and Marquez 2006). Focusing on the relevancy of geographic proximity in banking finance, this paper aims to fill in such a research gap in current literature by investigating how bank competition in a wider regional area and neighbor states affects corporate innovation in home-state after the passages of deregulations.

This paper is motivated by the fact that banks always possess a certain degree of market power and price accordingly when borrowers are separated from geographically disparate banks. Based on spatial pricing discrimination, the traditional spatial competition models formalize the idea that the cost of credit for businesses and borrower-lender distance is negatively related (Park and Pennacchi 2009). The underlying rationale is that the proximity between a borrower and its lender would increase the costs (e.g. transportation) for borrowers to access alternative but distant banks, enabling local banks to gain a certain monopoly power in local markets and to charge higher prices on proximate borrowers. In contrast, the information asymmetry rationale concerns that proximity may give advantages to closer lenders in screening perspective borrowers (Hauswald and Marquez 2006) and monitoring loans (Almazan 2002). In the sense, firms would be more likely to receive better loan terms from local banks because the severity of the asymmetric information problem may intensify with distance, and distant banks are often not viable 
substitutes for local banks (Agarwal and Hauswald 2010). This has been evidenced by a significant negative association between the firm-bank distance and the likelihood that small firms seek to establish strong and long-term banking relationships (Petersen and Rajan 2002; Berger et al. 2005).

In terms of the relationship between bank competition and corporate innovation, existing literature has mainly focused on a local based relationship (e.g. Corgannia et al. 2015), where firms are supposed raise capital from local (i.e. home state) banks to finance innovation activities. Whereas, a possible substitute effect of neighbor market competition may exist if firms, especially those large and publicly listed firms, access a neighbor bank market for finance because of greater availability and/or lower prices. In addition, due to the competing conjectures, a research gap exists in terms of the role played by information in distant banking. To fill in such a gap, this paper focuses on corporate innovation activities that are inherently risky and informationally opaque (Hall and Lerner 2010). If borrower proximity facilitates the collection of proprietary information, local banks would play a more important and favorable role in financing corporate innovation than distant banks. Therefore, our main propositions are, first, corporate innovation, especially those informationally opaque innovation activities, would be less sensitive to the structure of distant banking market (e.g. neighbor state) and second, asymmetric access to soft information over distance would provide local banks an advantage in information acquisition against distant competitors.

We commence our analysis by revisiting the favorable effects of banking market competition on corporative innovations by testing the heterogeneous sensitivities of innovation activities to bank competition within home-state and in a wider regional area. By employing Panzar-Rosse (1984) H-statistic ( $H$ henceforth) and consistent with existing literature (Amore et al. 2013; Chava et al. 2013; Cornaggia et al. 2015), we show clear evidence on the favorable effect of bank competition on corporate innovation. Contributing to banking literature, we also show that home-state bank competition exerts a stronger favorable effect than that of regional competition and such variation is economically sizable. For example, a 0.1 increase in home-state $H$ would improve the numbers of patents and citations by $20 \%$ and $49 \%$ respectively, while such an improvement of regional $H$ is only $3.5 \%$ for patents and $7.95 \%$ for citations. 
Moreover, we show that a greater competition in a wider regional market does not directly affect the underline nature and risks of innovation being patented. The unique evidence is in favor of the arguments on geographic proximity that physical distance acts as a source of inefficiency in credit markets and incurs economic costs for both lenders and borrowers (e.g. Degryse and Ongena 2004).

This paper also adds value to literature in a spatial analysis of banking market by testing the role of bank competition in neighbor states in financing corporate innovation in home state. We provide a more nuanced answer to the question that how spatial interdependency on competition may alter the importance of local banks on commercial lending. Yet such an effect has been neglected by existing literature due to the lack of reliable data. Aiming to fill in this research gap, we follow Bellón (2016) and propose a novel testing group to evaluate the substitution effects exercised by bank competition in neighbor states on corporate innovation.

The strategy is based on the overlap between financial and industrial markets (Asker and Ljungqvist 2010) on the determination of demand for credits in a local bank market. In specific, we propose that firms operating over larger geographical areas would be more sensitive to the structure of more than one 'local' banking market. This is because their non-local industrial competitors are affected by bank competition in their own home markets and there have been lower barriers for non-local banks to lend in other markets since bank deregulation. We show that the substitution effects of bank competition on corporate innovation do exist but for those firms operating in a wider geographic area only. In contrast, firms operating locally are not sensitive to bank competition in neighbor states and they reply much more heavily on local bank (Rajan and Zingales, 1998; Nanda and Nicholas, 2014), in a corporate innovation setting.

Due to the inefficiency of banking in screening and monitoring distant borrowers, we further investigate the role played by information. Our results show novel evidence that financially constrained firms and those innovation activities with a greater degree of proprietary information would benefit a stronger favorable effect from local (home-state) bank competition. Compared with informationally opaque innovators, informationally more transparent innovators benefit more from bank competition in neighbor states. Such a finding confirms the disadvantages of distant banks in information collection and supports 
the heterogeneity of bank competition effects (Petersen 2004; Stein 2002). It is also consistent with Dell'Ariccia and Marquez (2004) and Hauswald and Marquez (2006) who speculate that greater competition from outside lenders might cause local banks to concentrate their lending on proximate borrowers for whom they retained an information advantage.

The remainder of the paper proceeds as follows. Section 2 reviews relevant literature on the effects of bank market competition on credit availability and, thereby, the corporate innovation. We provide background information on bank competition in U.S in Section 3 and describe data, variables and identification strategies in Section 4. Sections 5 and 6 report the results from empirical analysis and robustness tests. We further investigate the effects of asymmetric information in Section 7 and conclude in Section 8.

\section{Theoretical Backgrounds}

The roles played by banking market structure have been widely acknowledged (e.g. Berger et al. 2005; Beck and Demirgüç-Kunt 2006). As a lingering debate, the theoretical predictions have presented both positive and negative relationships between banking competition and credit availability for firms and their innovation activities. According to the market power hypothesis, corporate innovation would benefit from banking market competition because of the improved credit supply (Boot and Thakor 2000), lowered credit prices (Black and Strahan 2002), decreased covenant intensity (Lian 2014) and improved bank operating efficiency (Benfratello et al. 2008). In contrast, information-based hypothesis proposes that banks in a concentrated market would have a stronger motive to acquire private information, e.g. by relationship lending, than those in competitive markets because of the free-riding issues (Diamond 1984; Dell'Ariccia and Marquez 2004). The credit supply to informationally opaque and financially constrained firms and projects, therefore, could be greater in a concentrated banking market where banks subsidize high risk borrowers at the beginning of the relationship and extract rent in the future from those who are eventually successful (Petersen and Rajan 1995). 
Building on the seminal paper by Hotelling (1929), a focus on location and spatial interaction in competition has recently gained more attention. Such a focus is attributed to the growing interest within theoretical economics that moves towards an explicit accounting for the interaction of an economic agent with other heterogeneous agents in the system (LeSage 2014). In a banking market, this is especially important where banks offer horizontally differentiated products and services. Intuitively, competition between banks is inherently spatial as borrowers would have to travel between banks or bank branches to complete different transactions, despite the improvement in information processing ( Berger and DeYoung 2006) and communication technologies (Pana et al. 2015). Hence, economic theories have taken physical distance as a source of inefficiency in credit markets, causing economic costs for both banks and borrowers (Degryse and Ongena 2004).

The first channel through which distance may affect the availability and cost of credit for firms is transportation costs. Formalized in the context of location, the traditional product differentiation models predict a negative relationship between loan prices and the borrower-lender distance. The rationale lies in the fact that closer borrowers face higher transportation costs to approach competing banks that are located farther away. This allows the lending bank to engage in spatial price discrimination on the basis of the physical distance to the borrowing firms (Dell'Ariccia 2001; Petersen and Rajan 2002; Park and Pennacchi 2009).

For banks, the total costs of monitoring are also expected to increase with the borrower-lender distance, reducing the willingness of banks to extend credits to more distant borrowers (Brevoort and Wolken 2009). The increasing monitoring costs may open another window for banks to engage in further discriminatory pricing by subsequently passing along such costs to borrowers by setting higher loan rates. Empirical evidence has shown that even a stronger bank competition reduces loan prices due to the decreased average distances between all possible combinations of firms and neighbor banks (Degryse and Ongena 2005), an increase in the number of banks aggravates the adverse selection problem by enabling low-quality borrowers to obtain finance (Broecker 1990), leading to a retrenchment towards relationship lending (Hauswald and Marquez 2006) and resulting in higher loan rates. Therefore, proximity of the 
borrower to an alternative (nearest competing) lender is another significant element in the relationship between distance and business lending.

The second rationale refers to information asymmetries as bank lending is an information intensive process by which banks collect relevant information from both borrowers and local markets (Wu and Wang 2000; McKee and Kagan 2017). If the severity of the asymmetric information problem intensifies with distance, banks can strategically use their informational advantage to create a threat of adverse selection for their rivals, and thus soften competition. Hence, this mechanism concerns the advantage that proximity may give local lenders in screening perspective borrowers and monitoring loans, particularly in lending small or informationally opaque businesses where banks ${ }^{3}$ rely more heavily on 'soft' information collected through multiple interactions with the firms via relationship banking for instance. The relationship lending is accumulated over time and therefore is costly to lenders and not easily transferable (Petersen 2004; Stein 2002). Indeed, the costs of building and sustaining the banking relationship are positively associated with the physical distance between the lender and borrower where farther away loan applicants are more likely to be credit rationed and lending decisions become less efficient with increasing distance (Carling and Lundberg 2005).

\section{Bank Competition in U.S}

The U.S. banking industry has changed dramatically over the past decades in response to a nationwide deregulation in banking sector. Coincided with the development of information technology and communications, interstate banking deregulation and the ability of bank holding companies (BHCs) to operate at a nationwide level have led to a significant consolidation wave in banking industry during late 1990s and an effective expansion of the banking market (Strahan 2003; Chang 2010; Al-Khasawneh 2013).

\footnotetext{
${ }^{3}$ Bank customers may undertake additional information costs related to searching information about alternative suppliers. These searching costs may vary directly with the distance between the customer and financial institutions and the degree of heterogeneity in financial services. Providing information to prospective customers can also impose costs on financial institutions in the form of advertising or the costs associated with maintaining relationships with brokers or other agents that interact with potential customers (Brevoort and Wolken 2009).
} 
In spite of the advance of disintermediation, U.S. banking sector has grown in real terms (Berger et al. 1995) and become more open to competition. The restructuring has raised numerous concerns about the conduct and performance of commercial banks and underlined the importance of both localized and multimarket competition in banking.

Some advocates of reform claim that the Riegle-Neal Interstate Banking and Branching Efficiency Act (IBBEA) of 1994 has made the operation of banking institutions more efficient in U.S by removing barriers to geographic expansion and helped BHCs better diversify their assets and liabilities. One of the most important implications, with regard to credit availability, is that fewer restrictions across states can improve the scope for geographic diversification, allowing banks to finance more freely across state boarders. The consolidation activity has increased the 'geographical reach' of banks substantially (Kwast et al. 1997; Berger et al. 1999; Brevoort and Hannan 2006). The lowered costs and the much improved ability to transmit information almost globally have effectively freed the financial service industry from the constraints of time and spaces. These changes have sparked a renewed interest in the fundamental role of bank-borrower distance in lending behavior in a less regulated environment.

For example, Dell'Ariccia and Marquez (2004) theoretically model how the extension of credit in local markets would be affected by the changes in either the cost advantages of the less-informed banks or in the degree of information asymmetries among financial institutions. They propose that a greater competition from outside lenders will motivate local banks to reallocate credit towards borrowers from whom they possess an information advantage, and encourage local lenders to reduce the distance over which they extend credit to businesses. Consistent with this view, Kroszner and Strahan (1999), Petersen and Rajan (2002) and Brevoort and Hannan (2006) propose that the proximity between borrowers and distant lenders is now less important than in the past. This is because advances in computing and communications technology have increased the availability of quantifiable information about potential borrowers and reduced the importance of 'soft' information, especially in small business lending. All these research efforts conclude that the structure changes in the competitive environment might lead local lenders to restrict their lending activities to a smaller geographic area. However, this question has not been the 
subject of extensive empirical study due to the unavailability of data. By using innovation data from companies who have access to both local and distant bank markets, this paper aims to evaluate the heterogeneous effects of bank competition on corporate innovation.

\section{Data and Methodology}

\subsection{Data collection}

We collect data from various sources. Within a patent-metrics, we collect corporate innovation data from National Bureau of Economics Research (NBER) patent database (1976-2006) which contains information on the patents granted by the United States Patent and Trademark Office (USPTO). We exclude patents granted to universities, governments and foreign companies who have weak dependency on local banking markets. The banking market competition is evaluated at state level for 51 states in U.S. by using bank deposit data from Federal Deposit Insurance Corporation (FDIC). The data is based on the values disclosed at the end of each fiscal year by commercial, cooperative and saving banks operated in U.S., and we exclude Hawaii and Alaska which do not have neighbors when investigating the substitution effects of bank competition. Finally, all firm-level information for control variables is collected from COMPUSTAT for listed corporations, and state specific control variables are obtained from Federal Reserve Bank of ST. Louis and National Venture Capital Association (NVCA). We restrict our data between 1992 and 2004 so as to have a full set of information on both patents and banking markets ${ }^{4}$.

\subsection{Measuring corporate innovation}

Following existing literature (e.g. Amore et al. 2013), we measure corporate innovation by patent-metrics. It prevents the problems arising from accounting practices, such as R\&D expenditure (Chava et al. 2013), and it better represents the output or the commercialization of innovation activities than other measures

\footnotetext{
${ }^{4}$ More recent data on bank market structure are available from FDIC and we find bank market has become less competitive (measured by Panzar-Rosse H Statistics) since financial crisis. Upon availability of more recent data on patent, future research could look into how financial crisis and reduced bank competition affect corporate innovation. We appreciate an anonymous referee for raising this point.
} 
(Ciftci and Zhou 2016). In specific, we measure innovation outputs by the number of patents filed by company $i$ in state $j^{5}$ in year $t$ and the number of citations received by the patents to capture the economic importance of innovation activities ${ }^{6}$ (Hall et al. 2001). We also use additional patent-based measures to evaluate the underlying risk and nature of corporate innovation activities. First, we make a distinction between highly cited (top quartile) patents (HighCited) and less frequently cited (bottom quartile) patents (LowCited) to measure the underlying risk of particular innovation activities (Chava et al. 2013). Second, we measure the nature of a specific patent by the indices of Generality and Originality. The greater the value of Generality, the more likely the patent is being drawn upon by a more diverse array of subsequent patents. Similarly, a patent would have a greater Originality if it cites a wider array of technology classes of patents. All variable constructions are provided in Appendix.

\subsection{Measuring banking market competition and controlling for endogeneity}

To establish the complex causality between the changes in bank competition and corporate innovation, we use Panzar-Rosse (1984) H-statistic $(H)^{7}$ with a long term equilibrium in the main tests and HerfindahlHirschman Index $(H H I)$ in the robustness tests. $H$ has been acknowledged to be superior to other competition measures as it is derived from profit-maximizing equilibrium conditions (Shaffer 2004; Claessens and Laeven 2005) and it has been widely used to assess banking market competition (Bikker and Haff 2002), ranging from 0 (monopolistic market) to 1 (competitive markets). Our measures of bank competition at either state or regional level consider all banks operating in a specific state or region, including both local banks and those which headquarter in other states. In addition, such measures are built on market equilibrium to minimize the interest rate dispersion effects caused by multi-locational nature of banks (Barros 1999).

\footnotetext{
${ }^{5}$ We match NBER patent data with COMPUSTAT sample firms by using a bridge file provided by the NBER database in which GVKEY is the common identifier. For cases in which the corporate headquarter is different from the assignee state, we use the headquarter state of the corporation shown in COMPUSTAT.

${ }^{6}$ We follow existing literature to date patents to the year of application to reflect the signaling effects and weight-average the number for three years to mitigate the truncation bias. Please see Appendix, Hall et al. (2001 and 2005) and Cornaggia et al (2015) for more detail.

${ }^{7}$ The derivation and equilibrium test of $H$ is not reported but available from authors upon request.
} 
Unlike exogenous shocks (e.g. the implementation of IBBEA), bank competition in a local banking market could be jointly determined with corporate innovation decisions by unobserved state characteristics. To address the possible endogeneity issue ${ }^{8}$, we apply an instrumental variable approach to overcome the endogenous problem and the instrument used is 'state median Tier 1 risk-based capital ratio. The idea relies on the fundamental nature of competitive markets where new players enter the market freely and failed players exit freely. A market with high regulated bank capital ratio would have a greater ability to build a buffer against unexpected losses (e.g. Corbae and D’Erasmo 2014) and such capital regulation directly constrains the entry of distant banks into a local market. Thus, a state with higher capital requirements are subject to less systemic risks of instability and tend to have limited entry and exit if the incumbent banks operate prudently, leading to a lower competitive banking market ${ }^{9}$.

To be a valid instrument, we have no reason to believe that performed capital ratio of banks directly affects corporate innovation activities. In fact, the Tier 1 ratio measures how well banks are capitalized in a particular market and the current Tier 1 ratio in U.S. is based on Basel III and enforced jointly by Office of the Comptroller of the Currency (OCC), Board of Governors of the Federal Reserve System and FDIC. Moreover, the required capital for de novo banks varies largely from one state to another though the impacts of regulations may be homogeneous. Therefore, Tier 1 ratio is anticipated to be valid instrument ${ }^{10}$ for $H$.

\subsection{Additional control variables}

In the regression analysis, we set a vector of corporation and industry characteristics that may affect a corporation's future innovation outputs as control variables. In conjunction with the literature on the economics of technological change and industrial organization (e.g. Cohen 1995), competitive position,

\footnotetext{
${ }^{8}$ The existence of endogeneity of local banking market competition is supported by Wu-Hausman F test $(\mathrm{p}=0.0632)$ and DurbinWu-Hausman chi-sq test $(\mathrm{p}=0.0225)$ in our empirical analysis.

${ }^{9}$ The correlation between state average $H$ and state median Tier 1 risk-based capital ratio during 1992 to 2004 is -0.1718 and is significantly different from zero at the $1 \%$ level.

${ }^{10}$ We use median Tier 1 ratio rather than regulatory minimum because banks might be still undercapitalized even they have such a ratio above minimum. To test the validity of the instrument, we conduct additional tests to investigate (1) if there is any relationship between Tier 1 ratio and innovation, (2) if the implementation of Basal Core Principles for Effective Banking Supervision in 1997, on which Tier 1 ratio is based, has any impact on innovation and (3) the robustness of the results by using an alternative instrument, tangible capital ratio. Our results, not reported but available on request, show consistent evidence on the validity of the instrument (Tier 1 ratio) used. We appreciate two anonymous referees for raising this issue.
} 
internal work routines and attitude to learning and communication - in terms of a firm's riskiness, efficiency and pledge ability - are consistently found to be associated with corporate innovative activities (e.g. Herrera and Minetti 2007). We expect that there are three key factors determining firms' innovative behavior.

Firstly, in accordance with Schumpeterian hypotheses (Schumpeter 1942) and well-established literature (e.g. Cohen and Klepper 1996b), the size of the firm and the level of product market concentration in which the firm operates are possible determinants of corporate innovation. Considering the role of industry factors, firms usually acquire market power because successful innovation or market power enables firms to make innovation profitable (Kamien and Schwartz 1982). Secondly, as with the scientific opportunity and appropriability theories, corporate profitability and leverage have been found to have a strong impact on corporate innovation (e.g. Himmelberg and Petersen 1994; Audretsch 1995) because the promotional effect of firms' profitability on their innovation activities is subject to the technological opportunity environment. Thirdly, it is useful to reconsider the Schumpeterian hypothesis in light of the fact that industry concentration may occur because of the existing relationship between innovation and corporate efficiency (Herrera and Minetti 2007). Therefore, following existing literature (e.g. Aghion et al. 2005), we control for both firm and state characteristics that may affect corporate innovation outputs, such as firm size, age, profitability (ROA), cash holding, growth opportunity (sales and Tobin's Q), asset tangibility, leverage, capital to labor ratio, and industry concentration. At state level, we control for coincident index (Crone and Clayton-Matthews 2005) and venture capital ratio which proxy for the timevariation in the availability of alternative financing sources for corporate innovation ${ }^{11}$. We winsorize all control variables at $1^{\text {st }} / 99^{\text {th }}$ percentile and variable definitions are provided in Appendix.

\footnotetext{
${ }^{11}$ Apart from venture capital, other nonbank sources of finance may also have impacts on corporate innovation. Our data do not allow us to further investigate such impacts and we call for future research to examine the effects of bank-nonbank competition on corporate innovation. We appreciate an anonymous referee for raising this point.
} 


\subsection{Summary statistics}

Table 1 reports the descriptive statistics for the variables used in the following analysis with a total of 32,869 firm-years observations from 49 U.S. contiguous states during 1992 - 2004. On average, each sample firm is granted 11 patents which receive a total of 137 citations annually. The local (home-state) banking market is monopolistically competitive. $H(H H I)$ ranges from $0.114(0.012)$ to $1(0.551)$ with an average of $0.594(0.01)$ and a standard deviation of $0.239(0.397)$. The market structure of neighbor state and a wider regional area show a similar pattern with monopolistic competition.

\section{[Table 1 insert here please]}

\subsection{Identification strategy and regression specifications}

Due to the limitation of the data, we are not able to match each sample firm with the market power of an individual bank, either in local market or distantly, which has financial transactions with the firm. Instead, we follow existing literature (e.g. Amore et al. 2013) and test the sensitivity of corporate innovation to the structure of local, neighbor and regional bank market by

$$
\begin{aligned}
& \ln (\text { Innovation })_{i t}=\alpha_{1}+\beta_{1} \widehat{H_{j t}}+\gamma_{1 n} \sum Z_{n, i t}+\text { Industry }_{k}+\text { Year }_{t}+\varepsilon_{1 i t} \\
& \ln \left({\text { Innovation })_{i t}}=\alpha_{2}+\beta_{2} \text { Reglon_}_{-} H_{r t}+\gamma_{2 n} \sum Z_{n, i t}+\text { Industry }_{k}+\text { Year }_{t}+\text { State }_{j}+\varepsilon_{2 i t}\right. \\
& \ln \left(\text { Innovation }_{i t}=\alpha_{3}+\beta_{3} \text { Neigh_H }_{j t}+\gamma_{1 n} \sum Z_{n, i t}+\text { Industry }_{k}+\text { Year }_{t}+\text { State }_{j}+\varepsilon_{1 i t}\right.
\end{aligned}
$$

where $i, t, j, r$ and $k$ represent company, time, state, region and industry respectively. Innovation ${ }_{i t}$ is corporate innovation for company $i$ in state $j$ year $t$, measured as patents, citations and etc. $\widehat{H_{J} t}$ and Reglon_$H_{r t}$ are the 'Tier 1 risk-based capital ratio' instrumented local (home state) and regional bank competition and their coefficient, $\beta$, captures the causal effect of $H$ on corporate innovation outcomes. $Z_{i t}$ 
denotes a vector of firm- and state-level controls. We also control for the aggregate trends in industry, year and state ${ }^{12}$ fixed effects.

$N e i g h_{-} H_{j t}{ }^{13}$ is the average $H$ of state $j$ 's neighbor states. As locational information always presents contiguity (LeSage 1999), empirically, we consider the importance of spatially heterogeneous relationships and define the average $N e i g h_{-} H_{j t}$ on the basis of inverse distance weights $W$. Given the latitude-longitude coordinates of a state, the weights matrix $W(49 \times 49)$ is as:

$$
W=\frac{w_{j l}^{*}}{\sum_{l} w_{j l}^{*}}
$$

where

$$
w_{j l}^{*}=\left\{\begin{aligned}
\frac{1}{d_{j l}}, & \text { if } j \neq l \text { and } l \in N_{K}(j) \text { or } j \in N_{K}(l) \\
0, & \text { otherwise }
\end{aligned}\right.
$$

and $d_{j l}$ stands for the great circle distance between centroids of state $j$ and $l$. In robustness tests, we use alternative binary weights that equal to 1 when state $j$ and $l$ share a common boundary.

Secondly, we consider the heterogeneous corporate demands for credit. Due to the overlap between financial and industrial markets (Asker and Ljungqvist 2010), it is anticipated that the access to cheaper finance in a competitive bank market would offer a business a strategic advantage in the product market over its competitors in a concentrated bank market, known as indirect competition in banking sector (Osborne 1988). Therefore, the geographical span of industrial markets in which firms operate may affect their demand for credit. We expect that firms with wider areas of operation, encompassing several banking markets, will have a more elastic demand for credit from their local banks, effectively limiting the available rent that the local banks can extract and are more sensitive to the product prices offered by their industrial

\footnotetext{
${ }^{12}$ Concerning the potential bias that is caused by multicollinearity, we exclude the state fixed effects from Eq.(1) since $H_{j t}$ is defined at state $\times$ year level. The identification of $\beta 1$, therefore, is not solely from within-state variation across time (Chava et al., 2013).

${ }^{13}$ We test the effects of home-state $\mathrm{H}$ and neighbour-state $\mathrm{H}$ in separate models. This is because the interdependence between $H_{j t}$ and $N e i g h_{-} H_{j t}$ may cause a potential multicollinearity problem. In addition, the main purpose of the paper is to investigate whether commercial lending markets in neighbor states can alter the impacts of localized banks (i.e. substitution effects) rather than the spillover of banking competition.
} 
competitors located in other states (Bellón 2016). Accordingly, we follow Porter (2003) and identify sample firms in traded industries ${ }^{14}$ that operate in a wider geographical area are more likely to be affected by unobservable heterogeneity in the locations where they are headquartered but the interest rates they face are less subject to the exercise of market power by local banks. While, firms that operate in other industries that compete against others within one geographical market may be more sensitive to the change of conditions of local banking market where they are located. To capture the causal (substitution) effects of localized and neighboring banking markets, we estimate the specification as:

$$
\begin{aligned}
& \ln (\text { Innovation })_{i t}=\alpha_{1}+\beta_{1} \widehat{H_{J t}}+\beta_{2} \widehat{H_{J t}} \times \text { Traded_firm }_{i}+\beta_{3} \text { Traded_firm }_{i}+\gamma_{1 n} \sum Z_{1 n, i t}+ \\
& \gamma_{2 n} \sum Z_{2 n, j t}+\text { Industry }_{k}+\text { Year }_{t}+\varepsilon_{i t} \\
& \ln (\text { Innovation })_{i t}=\alpha_{2}+\beta_{1}^{\prime} \text { Reglon_} H_{r t}+\beta_{2}^{\prime} \text { Reglon_} H_{r t} \times \text { Traded_firm }{ }_{i}+\beta_{2}^{\prime} \text { Traded_firm }{ }_{i}+ \\
& \gamma_{1 n}^{\prime} \sum Z_{1 n, i t}+\gamma_{2 n}^{\prime} \sum Z_{2 n, j t}+\text { Industry }_{k}+\text { Year }_{t}+\text { State }_{j}+\varepsilon_{i t} \\
& \ln (\text { Innovation })_{i t}=\alpha_{2}+\beta_{1}^{\prime \prime} N e i g h_{-} H_{j t}+\beta_{2}^{\prime \prime} N e i g h_{-} H_{j t} \times \text { Traded_firm }{ }_{i}+\beta_{2}^{\prime \prime} \text { Traded_firm }{ }_{i}+ \\
& \gamma_{1 n}^{\prime \prime} \sum Z_{1 n, i t}+\gamma_{2 n}^{\prime \prime} \sum Z_{2 n, j t}+\text { Industry }_{k}+\text { Year }_{t}+\text { State }_{j}+\varepsilon_{i t}
\end{aligned}
$$

where Traded_firm Tr $_{i}=1$ if a sample firm competes in wider geographical markets beyond home-state and Traded_firm $_{i}=0$ if it competes within only one geographically local market

\section{Empirical Results}

5.1 The effects of home-state bank competition on corporate innovation

We start our empirical analysis by examining the effects of bank competition in home states on the quantity and quality of corporate innovation, in terms of the numbers of patents obtained by sample firms and the number of citations received by the patents (Table 2). For ease of comparison, we firstly report the pooled OLS estimates in Models 1 and 6 with cluster standard errors by firms. In Models $2-5$ and $7-10$, instead,

\footnotetext{
${ }^{14}$ We only measure two clusters in our estimations. The resource based clusters in Porter (2003) are considered as local industries because employment in these industries is located primarily where the needed natural resources are found, although the industries somewhat compete with other domestic or international locations.
} 
we consider the endogeneity of $H$ by instrumenting $H$ and running 2SLS models. To test the validation of our instrument, we perform the first-stage regressions and the estimates are reported separately in Table 2, where the estimated coefficient of Tier 1 ratio on $H$ is negative and statistically significant at $1 \%$. In addition, the F-statistic of the first-stage regression is large enough with a statistically significant $p$-value, suggesting that Tier 1 ratio is a valid instrument for $H$ in our estimation.

Table 2 shows consistent evidence with existing literature on the facts that bank competition in home-state enhances innovative activities where firms would have better access to bank finance in a more competitive market, supporting market power hypothesis (Boot and Thakor 2000; Black and Strahan 2002). In addition, supporting our conjecture, Table 2 shows that traded firms, which operate in a much wider geographic area, are less sensitive to local bank competition (Models 5 and 10) than other firms operating locally. The difference of economic magnitude is significant. For example, a 0.1 increase in $H_{j t}$ would increase the number of patents (citations) by 19\% (47\%) for traded firms but 34\% (90\%) for other firms. Such a result is also robust to a grouping approach (Models 3 and 4 on patents and Models 8 and 9 on citations).

\section{[Table 2 insert here please]}

By following the same logic, we further investigate the effects of local bank competition on additional four patent-based innovation measures and report the results in Table 3 . Table 3 shows that consistent with above findings but except for innovation originality, businesses operating in local product markets (Traded_firm ${ }_{i}=0$ ) enjoy a stronger favorable effect of improved bank competition in homestate. It also shows that bank competition has a stronger favorable effect on high risk innovation activities (LowCited) (Models 2 vs. 4) where the size of coefficient of $H$ is more than 4 times greater for high risk innovation (Model 2) than for low risk innovation. Such a result suggests that an increased bank competition would supply more credits to firms undertaking high risk innovation activities and the innovation at initial and uncertain stage would take more advantages from a greater competition in local banking market. Finally, we find that bank competition improves the generality of corporate innovation.

\section{[Table 3 insert here please]}




\subsection{Regional bank market competition and corporate innovation}

Table 4 presents the regression results of Eq. (2) and (7), examining the effects of regional banking competition $\left(\right.$ Region_ $\left.H_{r t}\right)$ on the level of corporate innovative outputs. To address the potential endogeneity of $H$ at a regional level, we follow the same identification strategy and employ regional median Tier 1 risk-based capital ratio (Region_Tier 1 ratio $_{r t}$ ) as an instrument. The first stage regression is reported in the last column, showing the estimated predictions and validations of the instrument employed.

Table 4 shows that the coefficients of regional $H$ are positive and statistically significant at $1 \%$ level in all 2SLS estimations, where the dependent variables are the numbers of successful patent applications (Model $1-3$ ) and citations (Model 4-5), respectively. Even though, there is a significant drop in the magnitude of the coefficients compared with that of home-state $H$ (Table 2). An increase of home-state $H$ by 0.1 would increase patent counts by $20 \%$ (Model 2, Table 2) and $49 \%$ in citations (Model 7, Table 2). In contrast, the economic significance of regional $H$ is $3.5 \%$ for patent counts (Model 2) and 7.9\% for citations (Model 5). Moreover, the interaction effect between regional $H$ and industrial operations turns to be positive and economically significant (Model 3 and 6). This finding suggests that the improvement of banking competition within a greater geographical span is more beneficial for those firms that serve markets beyond the state in which they are located.

\section{[Table 4 insert here please]}

In addition, we perform the estimations against the underlying risk of corporate innovation and the results are reported in Table 5. Except for the effect on patents' generality scores (Model 5 and 6), we find little evidence in the effects of regional bank competition on the risk and originality of corporate innovation. Such evidence implies that bank competition within a wider scope of geographical areas appears to be less effective on explaining the nature of innovation patented. It might do because compared with local banks, distant banks always have a disadvantage in soft information collection over distance (e.g. Almazan 2002; Agarwal and Hauswald 2010).

\section{[Table 5 insert here please]}


5.3 Neighbor-state banking market competition and corporate innovation

Table 6 presents the estimations for Eq. (3) and (8), providing evidence in line with earlier findings on regional bank competition. First, it shows an overall favorable effect of bank competition in neighbor states on corporate innovation in home state (Models 1 and 5) but with smaller effects, compared with local bank competition (Table 2) and Second, our results suggest that such effects are only statistically significant for those businesses operating in a wider geographic product market (Models, 2, 4, 6 and 8). In addition, Table 7 shows little evidence on the effects of neighbor market completion on the nature of corporate innovation, in terms of risk, generality and originality. Overall, the results suggest that firms operating locally are not sensitive to bank competition of neighbor state and a wider geographic region. Therefore, 'how local is local banking market' depends on the operating scope of businesses. Compared with local banks, distant banks have an information disadvantage in financing informationally opaque corporate innovation activities and the magnitude of the favorable effects of bank competition decreases with distance.

\section{[Table 6 insert here please]}

\section{[Table 7 insert here please]}

\section{Robustness Tests and Parallel Trend Tests}

We undertake a rich set of robustness tests and our results are robust to a variety of identifications. First, we re-estimate our specifications by using Herfindahl-Hirschman Index ${ }^{15}(H H I)$ as an alternative proxy for bank competition. Table 8 shows consistent results that overall, bank concentration $(H H I)$ of both homestate market (Panel A) and neighbor state markets (Panel B) have unfavorable effects on corporate innovation and the innovation activities of those firms operating in a wider geographic area are more sensitive to neighbor state bank competition, confirming that our findings are not subject to the way of how

\footnotetext{
${ }^{15}$ We use the same instrument in estimating HHI and the correlation coefficient of state median Tier 1 risk-based capital ratio with $\mathrm{HHI}$ is 0.4973 significantly different from zero at a $1 \%$ level.
} 
banking market structure is measured. Our results are also robust to an alternative measure of neighbor market competition with alternative binary weight ${ }^{16}$.

\section{[Table 8 insert here please]}

In addition, we restrict the observation period from 1997 only in order to control for the potential effects caused by the implementation of IBEEA. The results in Table 9 indicate that our findings are not affected by the time trend and are not correlated with state policy shocks. Given the significant coefficients in Model 2 and 4, a 0.1 increase in $H$ in local home state banking markets would increase patents by $14 \%$ and citations by 53\% between 1997 and 2004. Although the evidence consistently suggests a favorable effect of local bank competition on corporate innovation, such a favorable effect of home-state $H$ has somewhat become smaller since 1997. In contrast, we find that the impacts of regional competition (Model 5 - 8) and neighbor-state $H$ (Model 9 - 12) have been improved after IBEEA. The finding provides evidence on the extended and integrated tendency of so-called local market in U.S. banking industry in a post deregulation period.

\section{[Table 9 insert here please]}

To further validate our earlier results with the parallel trend assumption (consistent estimate of $\beta_{3}$ in Eq. 6), there should be the same average change in outcome variables (innovation) for both firms operating with different scopes. However, such condition is difficult to test directly because the counterfactuals are unobservable. To assess whether there are any omitted interactions except for the one between bank competition $(H)$ and operating scope (Traded-firm), empirically, we test for systematic differences between the subgroups of our samples.

Table 10 shows that all subgroups in our sample share similar firm characteristics (Panel B). However, it could be the case that any systematic differential in investment opportunities between the traded and local firms might account for any empirical results, although all those important factors that may affect a corporation's innovation outputs have been parametrically controlled in the baseline specifications. To

\footnotetext{
${ }^{16}$ Results are not reported but available from the authors on request.
} 
ascertain whether such difference constitutes a problem for the robustness of our inferences, we group samples according to firm size, age and R\&D efficiency that are critical to reflect firms' information opacity, bargaining power and probability of success in innovation (e.g. Cohen and Klepper 1996a; Hirshleifer et al. 2013). Fitting the same model with the baselines (Eq. 6) for each subsample, the results ${ }^{17}$ show consistent favorable effects of local bank competition on corporate innovation in various subgroups. Therefore, our results still hold even if systematic different investment opportunities exist.

\section{[Table 10 insert here please]}

\section{Information Effects}

Existing banking literature has proposed that proximate borrowers would receive better loan terms from local banks because the severity of the asymmetric information problem may intensify with physical distance (e.g. Degryse and Ongena 2005; Agarwal and Hauswald 2010). This is probably more pronounced for distant banks to finance informationally opaque corporate innovation activities. Above analysis has shown consistent evidence that home-state bank competition improves corporate innovation, but one may concern that such a favorable effect may vary over the degree of business financial constraints and information asymmetries.

We expect that the positive home-state bank competition effects on innovation would be stronger for informationally opaque firms and those financially constrained firms. In order to test the conjecture, we group the sample firms according to their Kaplan-Zingales (1997) index and patent type distribution, as proxies for financial constraints and the level of information asymmetries at firm level, respectively. In light of the innovation literature, a greater information specialization poses a problem for the innovative firms when they come to terminating or initiating a banking relationship with banks, so that information differentiation captures the degree of specialization in relationship building (Boot and Thakor, 2000). If firms with intensive proprietary information cannot switch banks easily even if the rival banks from more

\footnotetext{
17 The estimated results of subsamples are not reported but available from authors on request.
} 
competitive markets tend to reduce loan prices, local banks may have advantages to extract information rents in the range of switching costs and the higher the degree of information specialization, the greater the rent a bank would create from information advantage.

We re-run Eq. (6) on sample firms with either low or high Kaplan-Zingales index and dispersed or concentrated patent type distribution. Table 11 shows that, first, our earlier results on the favorable effects of bank competition and their heterogeneity over business operation scope still hold. In addition, consistent with our expectation, the innovation activities, carried out by financially constrained firms (high KaplanZingales index) and by those with more concentrated patent type distributions, would benefit more strongly from increased home-state bank competition.

\section{[Table 11 insert here please]}

Following a similar logic, we examine the effects of neighbor state bank competition on corporate innovation (Table 12) and show that the favorable effects of neighbor state bank competition on corporate innovation are only statistically significant for those firms operating widely $\left(\right.$ Traded_firm $\left._{i}=1\right)$ but insignificant for those operating locally, supporting our conjecture on the disadvantages in information collection for distant banks.

\section{[Table 12 insert here please]}

\section{Conclusion}

This paper aims to complement the existing literature on bank competition and corporate innovation. Consistent with literature (e.g. Chava et al. 2013), we show evidence on the favorable effects of bank competition on corporate innovation, supporting market power hypothesis. In addition, our work contributes to knowledge by providing novel evidence on the information advantages local banks possess where locally operating firms benefit more from home-state bank competition than that in a wider region or in neighbor-states. 
Overall, our evidence lends support to the notion that the impacts of banking market competition would be different across borrowers characterized by different degrees of asymmetric information, financial constraints and operating scope. The more pronounced impacts on informationally opaque firms suggest that local banking competition plays a more important role in financing the innovation activities of local firms, in line with the propositions by Rajan and Zingales (1998) and Nanda and Nicholas (2014). We show that the substitution effects of bank competition do exist but are only significant for those firms operating widely. Such a substitution effect is not important for informationally opaque firms due to the inefficiencies in credit supply of distant banks. This can be attributed to the fact that the information provided by those opaque firms to their lenders cannot be transferred easily to distant lenders (Petersen 2004; Stein 2002). As such, distant banks generally face a higher degree of information asymmetries compared with local banks, reducing their willingness to extend credit to distant borrowers. Our empirical evidence on bank competition, therefore, suggests that 'how local is local' depends on the operating scope and information transparency of corporate borrowers.

Our results also offer two important implications. First, consistent to existing empirical evidence, our results show clear evidence on the favorable effects of bank competition on corporate innovation, not only locally at home state but overall in a much wider region. Therefore, bank competition should be encouraged by policy makers by removing barriers for lenders to enter a new regional market and for borrowers to access finance from a wider physical area. This would enable businesses to compete not only locally but also more widely with competitors in other regions. Second, the more pronounced effect of local banking competition on stimulating innovation highlights the important role played by local bank market. Their bank managers are encouraged to develop stronger banking relationships with local businesses to sustain their competitive advantages in information acquisition against external competitors.

\section{References}

Agarwal S, Hauswald R (2010) Distance and private information in lending. Rev Financ Stud 23(7): 27572788 
Aghion P, Bloom N, Blundell R., Griffith R, Howitt P (2005) Competition and innovation: An inverted-U relationship. Q J Econ 120(2): 701-728

Al-Khasawneh JA (2013) Pairwise X-efficiency combinations of merging banks: Analysis of the fifth merger wave. Rev Quant Finan Acc 41(1): 1-28

Almazan A (2002) A model of competition in banking: Bank capital versus expertise. J Financ Intermed 11(1): $87-121$

Amore MD, Schneiderb C, Žaldokas A (2013) Credit supply and corporate innovation. J Financ Econ 109(3): 835-855

Asker J, Ljungqvist A (2010) Competition and the structure of vertical relationships in capital markets. J Polit Econ 118(3): 599-647

Audretsch DB (1995) Innovation and Industry Evolution. MIT Press, Cambridge, MA

Barros PP (1999) Multimarket competition in banking, with an example from the Portuguese market. Int J Ind Organ 17(3): 335-352

Beck T, Demirgüç-Kunt A (2006) Small and medium-sized enterprises: Access to finance as a growth constraint. J Bank Financ 30(11): 2931-2943

Bellón C (2016) How local is a local banking market? Bank competition, borrower competition and interest rates. Research Paper http://dx.doi.org/10.2139/ssrn.2665173

Benfratello L, Schiantarelli F, Sembenelli A (2008) Banks and innovation: Microeconometric evidence on Italian firms. J Financ Econ 90(2): 197-217

Berger AN, Demsetz RS, Strahan PE (1999) The consolidation of the financial services industry: Causes, consequences, and implications for the future. J Bank Financ 23(2-4): 135-194

Berger A, DeYoung R (2006) Technological progress and the geographic expansion of the banking industry. J Money Credit Bank 38(6):1483-1513

Berger AN, Kashyap AK, Scalise JM (1995) The transformation of the U.S. banking industry: What a long, strange trip it's been. Brookings Pap Econ Act 26(2): 55-218 
Berger AN, Miller NH, Petersen MA, Rajan, RG, Stein JC (2005) Does function follow organisational form? Evidence from the lending practices of large and small banks. J Financ Econ 76(2): 237-269

Bikker JA, Haaf K (2002) Competition, concentration and their relationship: An empirical analysis of the banking industry. J Bank Financ 26(11): 2191-2214

Black S, Strahan PE (2002) Entrepreneurship and bank credit availability. J Finance 57(6): 2807-2833

Boot AWA, Thakor AV (2000) Can relationship banking survive competition? J Finance 55(2): 679-713

Brevoort KP, Hannan TH (2006) Commercial lending and distance: Evidence from community reinvestment act data. J Money Credit Bank 38(8): 1991-2012

Brevoort KP, Wolken JD (2009) Does distance matter in banking? In Pietro Alessandrini, Michele Fratianni and Alberto Zazzaro (Eds.) The Changing Geography of Banking and Finance, 27-56, Springer, Berlin Heidelberg

Broecker T (1990) Credit-worthiness tests and interbank competition. Econometrica 58(2): 429-452

Carling K, Lundberg S (2005) Asymmetric information and distance: An empirical assessment of geographical credit rationing. J Econ Bus 57(1): 39-59

Chang CP (2010) E-Finance, entry deterrence, and optimal loan rate of a potential entrant: An option-based valuation. Rev Pac Basin Finan Mark Pol 13(2): 287-307

Chava S, Oettl A, Subramanian A, Subramanian KV (2013) Banking deregulation and innovation. J Financ Econ 109(3): 759-774

Ciftci M, Zhou N (2016) Capitalizing R\&D expenses versus disclosing intangible information. Rev Quant Financ Account 46(3): 661-689

Claessens S, Laeven L (2005) Financial dependence, banking sector competition, and economic growth. J Eur Econ Assoc 3(1): 179-207

Cohen WM (1995) Empirical studies of innovative activity. In Paul Stoneman (Ed.) Handbook of the Economics of Innovation and Technical Change, Chapter 6, Wiley-Blackwell, Oxford

Cohen WM, Klepper S (1996a) A reprise of size and R\&D. Econ J, 106(437): 925-951 
Cohen WM, Klepper S (1996b) Firm size and the nature of innovation within industries: The case of process and product R\&D. Rev Econ Stat 78(2): 232-243

Corbae D, D'Erasmo P (2014) Capital requirements in a quantitative model of banking industry dynamics. Working Paper No. 14-13, Federal Reserve Bank of Philadelphia

Cornaggia J, Mao Y, Tian X, Wolfe B (2015) Does banking competition affect innovation? J Financ Econ 115(1): 189-209

Crone TM, Clayton-Matthews A (2005) Consistent Economic Indexes for the 50 States. Rev Econ Stat 87(4): 593-603

Degryse H, Ongena S (2004) The impact of technology and regulation on the geographical scope of banking. Oxf Rev Econ Pol 20(4): 571-590

Degryse H, Ongena S (2005) Distance, lending relationships, and competition. J Finance 60(1): 231-266

Dell'Ariccia G (2001) Asymmetric information and the structure of the banking industry. Eur Econ Rev 45(10): 1957-1980

Dell'Ariccia G, Marquez R. (2004) Information and bank credit allocation. J Financ Econ 72(1): 185-214

Diamond DW (1984) Financial intermediation and delegated monitoring. Rev Econ Stud 51(3): 393-414

Duchin R, Ozbas O, Sensoy BA (2010) Costly external finance, corporate investment, and the subprime mortgage credit crisis. J Financ Econ 97(3): 418-435

Hall BH, Jaffe AB, Trajtenberg M (2001) The NBER patent citation data file: Lessons, insights and methodological tools. NBER Working Paper No. 8498, National Bureau of Economic Research

Hall BH, Jaffe AB, Trajtenberg M (2005) Market value and patent citations. RAND J Econ 36(1): 16-38

Hauswald R, Marquez R (2006) Competition and strategic information acquisition in credit markets. Rev Financ Stud 19(3): 967-1000

Herrera AM, Minetti R (2007) Informed finance and technological change: Evidence from credit relationships. J Financ Econ 83(1): 223-269

Himmelberg CP, Petersen BC (1994) R\&D and internal finance: A panel study of small firms in high-tech industries. Rev Econ Stat 76(1): 38-51 
Hirshleifer D, Hsu PH, Li D (2013) Innovative efficiency and stock returns. J Financ Econ 107(3): 632654

Hotelling H (1929) Stability in competition. Econ J 39(153): 41-45

Kamien ML, Schwartz NL (1982) Market Structure and Innovation. Cambridge University Press, Cambridge, MA

Kaplan S, Zingales L (1997) Do investment-cash flow sensitivities provide useful measures of financing constraints? Q J Econ 112(1): 169-215

Kroszner RS, Strahan PE (1999) What drives deregulation? Economics and politics of the relaxation of bank branching restrictions. Q J Econ 114(4): 1437-1467

Kwast ML, Starr-McCluer M, Wolken JD (1997) Market definition and the analysis of antitrust in banking. Antitrust Bulletin 42: 973-995

LeSage JP (1999) The theory and practice of spatial econometrics. Working Paper, Department of Economics, University of Toledo

LeSage JP (2014) What regional scientists need to know about spatial econometrics. Rev Reg Stud 44(1): 13-32

Lian Y (2017) Bank competition and the cost of bank loans. Rev Quant Finan Acc. doi: 10.1007/s11156017-0670-9

McKee G, Kagan A (2017) Community bank structure an x-efficiency approach. Rev Quant Finan Acc. doi: 10.1007/s11156-017-0662-9

Michalski T, Ors E (2012) (Interstate) banking and (Interstate) trade: Does real integration follow financial integration? J Financ Econ 104(1): 89-117

Nanda R, Nicholas T (2014) Did bank distress stifle innovation during the great depression? J Financ Econ 114(2): 273-292

Osborne DK (1988) Competition and geographical integration in commercial bank lending. J Bank Financ 12(1): $85-103$ 
Pana E, Vitzthum S, Willis D (2015) The impact of internet-based services on credit unions: a propensity score matching approach. Rev Quant Financ Account 44(2):329-352

Panzar JC, Rosse JN (1984) Testing for monopoly equilibrium. J Ind Econ 35(4): 443-456

Park K, Pennacchi G (2009) Harming depositors and helping borrowers: The disparate impact of bank consolidation. Rev Financ Stud 22(1): 1-40

Petersen MA (2004) Information: Hard and soft. Northwestern University, Chicago, IL

Petersen MA, Rajan RG (1995) The effect of credit market competition on lending relationships. Q J Econ 110(2): 406-443

Petersen MA, Rajan RG (2002) Does distances still matter? The information revolution in small business lending. J Finance 57(6): 2533-2570

Porter ME (2003) The economic performance of regions. Reg Stud 37(6-7): 549-578

Rajan RG, Zingales L (1998) Financial dependence and growth. Am Econ Rev 88(3): 559-566

Rice T, Strahan PE (2010) Does credit competition affect small-firm finance? J Finance 65(3): 861-889

Richards TJ, Acharya RN, Kagan A (2008) Spatial competition and market power in banking. J Econ Bus 60(5): $436-454$

Schumpeter JA (1942) Capitalism, Socialism and Democracy. Harper and Row, New York

Sharpe S (1990) Asymmetric information, bank lending and implicit contracts: A stylized model of customer relationships. J Finance 45(4): 1069-1087

Shaffer S (2004) Patterns of competition in banking. J Econ Bus 56(4): 287-313

Stein J (2002) Information production and capital allocation: Decentralised versus hierarchical firms. J Finance 57(5): 1891-1921

Strahan, P.E. (2003) The real effects of U.S. banking deregulation. Working Paper No. 02-39, Wharton School Financial Institutions Center, Philadelphia, PA.

Wu C, Wang X (2000) A neural network approach for analyzing small business lending decisions. Rev Quant Financ Account 15(3): 259-276 


\section{Appendix: Variables construction}

\section{Innovation variables:}

$\ln (\text { Patent })_{i t}$ : Natural logarithm of one plus company $i$ 's total number of successful patents filed in years $t$, where the aggregated counts are adjusted by using the 'weight factors' computed from the application-grant empirical distribution and averaging the number of patents within three years (year $t$ to $t+2)$.

$\ln (\text { Citation })_{i t}$ : Natural logarithm of one plus company i's total number of citations received of its patents filed in years $t$, where the number of citations are corrected for truncation (Hall et al., 2001, 2005) and averaging within three years (year $t$ to $t+2)$.

$\ln (\text { HighCited })_{i t}$ : Natural logarithm of the number of patents applied by company $i$ in state $j$, year $t$, whose citations are above the $75^{\text {th }}$ percentile of year $t$ 's citation distribution in state $j$.

$\ln (\text { LowCited })_{i t}$ : Natural logarithm of the number of patents applied by company $i$ in state $j$, year $t$ whose citations are below the $25^{\text {th }}$ percentile of year $t$ 's citation distribution in state $j$.

Generality $_{i t}$ : An index equals to $1-\sum_{k}^{n_{k}} s_{k l}^{2}$, where $s_{k l}^{2}$ denotes the percentage of citations received by a patent $k$ that belongs to the patent technology class $l$ out of $n_{k}$ patent classes (Hall et al., 2001). It ranges between 0 and 1, and the higher a patent's generality score, the more that the patent is being drawn upon by a more diverse array of subsequent patents. In the analysis, we take an average value for all patents generated by the company $i$ in year $t$. For companies that generate no patents in a year, the index are undefined and therefore treated as missing.

Originality $_{i t}$ : An index equals to $1-\sum_{k}^{n_{k}} s_{k l}^{2}$, where $s_{k l}^{2}$ denotes the percentage of citations made by a patent $k$ that belongs to the patent technology class $l$ out of $n_{k}$ patent classes (Hall et al., 2001). It is bounded between 0 and 1, and the higher a patent's originality score, the more the patent draws upon a diverse array of existing knowledge. In the analysis, we take an average value for all patents generated by 
the company $i$ in year $t$. For companies that generate no patents in a year, the index are undefined and therefore treated as missing.

\section{Banking market competition variables:}

$H_{j t}$ : Panzar-Rosse (1984) H-statistic of the banking market in state $j$ year $t$, which is estimated by the sum of the elasticity of total revenue with respect to three inputs prices used by banks, which are the labor, funds and physical capital, ranging from 0 to 1 . The detailed derivation is available upon request from the authors.

Region_ $H_{r t}$ : Panzar-Rosse (1984) H-statistic of the banking market in region $r$ year $t$. The division of region areas follows the U.S. Census Bureau definitions, including New England, Mid-Atlantic, East North Central, West North Central, South Atlantic, East South Central, West South Central, Mountain and Pacific (http://www.census.gov/geo/maps-data/maps/pdfs/reference/us_regdiv.pdf).

Neigh_H $H_{j t}$ : Spatially average weighted Panzar-Rosse (1984) H-statistic of state $j$ 's K number of neighbor states in year $t$. Given the latitude-longitude coordinates of a state, in specific, the weights matrix $W(49 \times 49)$ is measured by $W=\frac{w_{j l}^{*}}{\sum_{l} w_{j l}^{*}}$, where $w_{j l}^{*}=\frac{1}{d_{j l}}$ if $j \neq l$ and $l \in N_{K}(j)$ or $j \in N_{K}(l)$. And in the robustness test, we measure $w_{j l}^{*}=1$ if $j \neq l$ and $l \in N_{K}(j)$ or $j \in N_{K}(l)$.

$H_{\text {HI }}\left(\right.$ Region_HHI $\left.I_{r t}\right)$ : Herfindahl-Hirschman Index, the sum of squared share of deposits for each branch in state $j$ (region $r$ ) year $t$. We take weighted averages across markets for banking institutions in multiple local markets using the proportions of total deposits as the weights.

Neigh_HHI $\mathrm{H}_{j t}$ : Spatially average weighted Herfindahl-Hirschman Index of banking concentration of state $j$ 's K number of neighbor states in year $t$, measured on the bases of inverse distance weights matrix $W$ $(49 \times 49)=\frac{w_{j l}^{*}}{\sum_{l} w_{j l}^{*}}$, where $w_{j l}^{*}=\frac{1}{d_{j l}}$ if $j \neq l$ and $l \in N_{K}(j)$ or $j \in N_{K}(l)$.

\section{Other control variables:}


Traded_firm ${ }_{i}$ : The measure of the geographical span of industrial competition. It takes value of one if a sample firm competes beyond one geographical product market and zero if it competes within only one geographical market.

Size $_{i t}$ : Natural logarithm of the book value of total assets of company $i$ measured at the end of fiscal year $t$.

$A g e_{i t}:$ Natural logarithm of $(1+a g e)$, where age is the number of years that the company $i$ has been in COMPUSTAT.

$R O A_{i t}$ : EBITDA to total assets for company $i$ in year $t$.

Cash holding $_{i t}$ : Cash and marketable securities to total assets for company $i$ in year $t$.

Asset tangibility $y_{i t}$ : Ratio of net property, plants and equipment (PPE) to total assets for company $i$ in year $t$.

Capital to labor ratio $_{i t}$ : Natural logarithm of the ratio for company $i$ in year $t$, where capital is represented by property, plants and equipment (PPE), and labor is the total number of employees.

Leverage $_{i t}$ : Debt to equity ratio of company $i$ in year $t$.

$\ln (\text { Sales })_{i t}$ : Natural logarithm of the total sales of company $i$ year $t$.

Tobin's $Q_{i t}$ : Equals to the total market value of company $i$ in year $t$ divided by its total assets value. According to Duchin et al. (2010), the market value = Total assets + Market value of common equity Common equity - Deferred taxes. The total assets value $=0.9 \times$ Book value of assets $+0.1 \times$ Market value of assets.

Product market $\mathrm{HHI}_{i t}$ : Herfindahl-Hirschman Index of the industry in which company $i$ operates, computed as the sum of squared market share of all firms, based on sales, in a given three-digit SIC industry in year $t$.

Coincident index $x_{j-1}$ : An index used to control for regional economic trend, which combines data on nonfarm payroll employment, average hours worked in manufacturing, unemployment rate, and wage and salary disbursements deflated by the consumer price index. 
Venture capital $_{j t}$ : Ratio of total venture capital investments to total investment in state $j$ year $t$.

Kapla_Zingales_index: A measure for the financial constraints at firm-level (Kaplan-Zingales, 1997) which is equal to $[-1.002 \times$ Cash flow $+0.283 \times$ Tobin's $Q+3.319 \times$ Debt $-39.368 \times$ Dividends -1.315 $\times$ Cash].

Patent distribution $_{i t}$ : A measure of specialized information of the innovation being patented. Based on 6 different patent categories defined by Hall et al. (2001), the innovative activity is considered as 'concentrated' if the kurtosis value of the empirical distribution of patents produced by company $i$ in year $t$ among different categories is greater than 3, otherwise is defined as 'dispersed'. 


\begin{tabular}{|c|c|c|c|c|c|}
\hline Variables & Obs & Mean & Std. dev. & Min & Max \\
\hline Patent $_{i t}$ & 32,869 & 11 & 76 & 0 & 3769 \\
\hline Citation $_{i t}$ & 32,869 & 137 & 922 & 0 & 42339 \\
\hline HighCites $_{i t}$ & 7,995 & 11 & 45 & 1 & 1207 \\
\hline LowCites $_{i t}$ & 5,889 & 10 & 27 & 0 & 566 \\
\hline Generality $_{i t}$ & 15,799 & 0.373 & 0.291 & 0 & 1 \\
\hline Originality $_{i t}$ & 15,799 & 0.526 & 0.243 & 0 & 1 \\
\hline$H$-statistic $\left(\boldsymbol{H}_{\boldsymbol{j} \boldsymbol{t}}\right)$ & 32,869 & 0.594 & 0.239 & 0.114 & 1.000 \\
\hline$H H I\left(\boldsymbol{H H I}_{\boldsymbol{j t}}\right)$ & 28,513 & 0.010 & 0.397 & 0.012 & 0.551 \\
\hline Average H-statistics of Neighboring state (Neigh_H $\boldsymbol{H}_{\boldsymbol{j} t}$ ) & 32,869 & 0.647 & 0.169 & 0.187 & 0.968 \\
\hline Distance weighted average $H$-statistics of Neighboring state (WNeigh_ $\left.\boldsymbol{H}_{j t}\right)$ & 32,869 & 0.644 & 0.252 & 0.085 & 1 \\
\hline Regional H-statistic (Region_H $\left.\boldsymbol{H}_{r t}\right)$ & 32,481 & 0.554 & 0.229 & 0.124 & 0.968 \\
\hline Size & 31,789 & 5.188 & 2.597 & -6.908 & 13.920 \\
\hline Age & 31,098 & 2.348 & 1.048 & 0 & 4.007 \\
\hline$R O A$ & 31,593 & -0.042 & 0.454 & -2.708 & 0.407 \\
\hline Cash holding & 31,774 & 0.227 & 0.258 & -0.008 & 1 \\
\hline Asset tangibility & 31,726 & 0.241 & 0.193 & 0 & 1 \\
\hline Capital to labor ratio & 29,432 & 4.321 & 1.053 & -1.792 & 11.598 \\
\hline Leverage & 30,440 & 0.011 & 0.040 & 0 & 1.450 \\
\hline Ln(Sales) & 30,927 & 4.963 & 2.813 & -6.908 & 12.564 \\
\hline Tobin's $Q$ & 32,869 & 1.325 & 8.963 & -229.930 & 1082.041 \\
\hline Product market HHI & 32,798 & 0.014 & 0.024 & 0.007 & 0.404 \\
\hline Coincident Index & 32,842 & 124.853 & 15.954 & 92.600 & 203.120 \\
\hline Venture capital ratio & 32,727 & 3.267 & 7.436 & 0 & 52.302 \\
\hline
\end{tabular}


Table 2 The Impacts of State Banking Market Competition on the Level of Corporate Innovation

\begin{tabular}{|c|c|c|c|c|c|c|c|c|c|c|c|}
\hline \multirow[t]{3}{*}{ Dependent variable } & \multicolumn{5}{|c|}{$\ln (\text { Patent })_{i t}$} & \multicolumn{5}{|c|}{$\ln (\text { Citation })_{i t}$} & \multirow{3}{*}{$\begin{array}{c}\qquad \boldsymbol{H}_{\boldsymbol{j} \boldsymbol{t}} \\
\text { First stage }\end{array}$} \\
\hline & \multirow{2}{*}{$\begin{array}{c}\text { OLS } \\
\text { All } \\
(1) \\
\end{array}$} & \multicolumn{4}{|c|}{ 2SLS } & \multirow{2}{*}{$\begin{array}{c}\text { OLS } \\
\text { All } \\
(6)\end{array}$} & \multicolumn{4}{|c|}{ 2SLS } & \\
\hline & & $\begin{array}{l}\text { All } \\
(2)\end{array}$ & $\begin{array}{c}\text { Traded } \\
\text { (3) }\end{array}$ & $\begin{array}{l}\text { Local } \\
\text { (4) }\end{array}$ & $\begin{array}{c}\text { Interaction } \\
\text { (5) }\end{array}$ & & $\begin{array}{l}\text { All } \\
(7)\end{array}$ & $\begin{array}{c}\text { Traded } \\
(8)\end{array}$ & $\begin{array}{l}\text { Local } \\
(9)\end{array}$ & $\begin{array}{c}\text { Interaction } \\
(10)\end{array}$ & \\
\hline Tier 1 ratio $_{i t}$ & & & & & & & & & & & $\begin{array}{c}-0.200 * * * \\
(0.006)\end{array}$ \\
\hline $\boldsymbol{H}_{j t}$ & $\begin{array}{c}0.028 \\
(0.033)\end{array}$ & $\begin{array}{c}1.801 * * * \\
(0.196)\end{array}$ & $\begin{array}{c}1.783 * * * \\
(0.199)\end{array}$ & $\begin{array}{c}4.198 * * * \\
(1.435)\end{array}$ & $\begin{array}{c}2.912 * * * \\
(0.581)\end{array}$ & $\begin{array}{c}0.203 * * * \\
(0.060)\end{array}$ & $\begin{array}{c}4.001 * * * \\
(0.352)\end{array}$ & $\begin{array}{c}3.958 * * * \\
(0.354)\end{array}$ & $\begin{array}{c}8.281 * * * \\
(2.796)\end{array}$ & $\begin{array}{c}6.425^{* * *} \\
(1.192)\end{array}$ & \\
\hline$H_{j t} \times$ Traded_firm ${ }_{i}$ & & & & & $\begin{array}{c}-1.177 * * \\
(0.559)\end{array}$ & & & & & $\begin{array}{c}-2.566 * * \\
(1.152)\end{array}$ & \\
\hline Traded_firm $_{i}$ & & & & & $\begin{array}{c}0.848^{* *} \\
(0.330)\end{array}$ & & & & & $\begin{array}{c}1.743 * * \\
(0.679)\end{array}$ & \\
\hline Size & $\begin{array}{c}0.215 * * * \\
(0.007)\end{array}$ & $\begin{array}{c}0.222 * * * \\
(0.007)\end{array}$ & $\begin{array}{c}0.240 * * * \\
(0.008)\end{array}$ & $\begin{array}{c}0.100 * * * \\
(0.032)\end{array}$ & $\begin{array}{c}0.222 * * * \\
(0.007)\end{array}$ & $\begin{array}{c}0.349 * * * \\
(0.013)\end{array}$ & $\begin{array}{c}0.364 * * * \\
(0.014)\end{array}$ & $\begin{array}{c}0.391 * * * \\
(0.015)\end{array}$ & $\begin{array}{c}0.184 * * * \\
(0.062)\end{array}$ & $\begin{array}{c}0.364 * * * \\
(0.014)\end{array}$ & \\
\hline Age & $\begin{array}{c}0.071 * * * \\
(0.008)\end{array}$ & $\begin{array}{c}0.082 * * * \\
(0.008)\end{array}$ & $\begin{array}{c}0.097 * * * \\
(0.009)\end{array}$ & $\begin{array}{l}-0.040 \\
(0.035)\end{array}$ & $\begin{array}{c}0.085^{* * *} \\
(0.008)\end{array}$ & $\begin{array}{c}0.036 * * * \\
(0.013)\end{array}$ & $\begin{array}{c}0.060 * * * \\
(0.014)\end{array}$ & $\begin{array}{c}0.084 * * * \\
(0.015)\end{array}$ & $\begin{array}{c}-0.136 * * \\
(0.068)\end{array}$ & $\begin{array}{c}0.064 * * * \\
(0.015)\end{array}$ & \\
\hline ROA & $\begin{array}{c}-0.349 * * * \\
(0.016)\end{array}$ & $\begin{array}{c}-0.348 * * * \\
(0.017)\end{array}$ & $\begin{array}{c}-0.376 * * * \\
(0.018)\end{array}$ & $\begin{array}{l}-0.079 \\
(0.070)\end{array}$ & $\begin{array}{c}-0.345^{* * *} \\
(0.017)\end{array}$ & $\begin{array}{c}-0.478 * * * \\
(0.032)\end{array}$ & $\begin{array}{c}-0.476^{* * * *} \\
(0.035)\end{array}$ & $\begin{array}{c}-0.527 * * * \\
(0.036)\end{array}$ & $\begin{array}{l}-0.018 \\
(0.149)\end{array}$ & $\begin{array}{c}-0.470 * * * \\
(0.035)\end{array}$ & \\
\hline Cash holding & $\begin{array}{c}0.589 * * * \\
(0.032)\end{array}$ & $\begin{array}{c}0.556^{* * *} \\
(0.034)\end{array}$ & $\begin{array}{c}0.584 * * * \\
(0.036)\end{array}$ & $\begin{array}{c}0.035 \\
(0.143)\end{array}$ & $\begin{array}{c}0.553 * * * \\
(0.034)\end{array}$ & $\begin{array}{c}1.125^{* * * *} \\
(0.060)\end{array}$ & $\begin{array}{c}1.053 * * * \\
(0.065)\end{array}$ & $\begin{array}{c}1.102 * * * \\
(0.069)\end{array}$ & $\begin{array}{c}0.358 \\
(0.283)\end{array}$ & $\begin{array}{c}1.050 * * * \\
(0.065)\end{array}$ & \\
\hline Asset tangibility & $\begin{array}{c}-0.551 * * * \\
(0.050)\end{array}$ & $\begin{array}{c}-0.611 * * * \\
(0.053)\end{array}$ & $\begin{array}{c}-0.554 * * * \\
(0.058)\end{array}$ & $\begin{array}{c}-0.746 * * * \\
(0.171)\end{array}$ & $\begin{array}{c}-0.586 * * * \\
(0.054)\end{array}$ & $\begin{array}{c}-0.824 * * * \\
(0.089)\end{array}$ & $\begin{array}{c}-0.954 * * * \\
(0.096)\end{array}$ & $\begin{array}{c}-0.848 * * * \\
(0.106)\end{array}$ & $\begin{array}{c}- \\
(0.316)\end{array}$ & $\begin{array}{c}-0.916 * * * \\
(0.099)\end{array}$ & \\
\hline Capital to labour ratio & $\begin{array}{c}0.107 * * * \\
(0.009)\end{array}$ & $\begin{array}{c}0.107 * * * \\
(0.009)\end{array}$ & $\begin{array}{c}0.087 * * * \\
(0.010)\end{array}$ & $\begin{array}{c}0.156^{* * * *} \\
(0.032)\end{array}$ & $\begin{array}{c}0.103 * * * \\
(0.010)\end{array}$ & $\begin{array}{c}0.134 * * * \\
(0.016)\end{array}$ & $\begin{array}{c}0.134 * * * \\
(0.017)\end{array}$ & $\begin{array}{c}0.092 * * * \\
(0.019)\end{array}$ & $\begin{array}{c}0.278^{* * *} \\
(0.060)\end{array}$ & $\begin{array}{c}0.129 * * * \\
(0.018)\end{array}$ & \\
\hline Leverage & $\begin{array}{c}-0.503 * * * \\
(0.170)\end{array}$ & $\begin{array}{c}-0.321^{*} \\
(0.172)\end{array}$ & $\begin{array}{l}-0.234 \\
(0.182)\end{array}$ & $\begin{array}{l}-0.278 \\
(0.649)\end{array}$ & $\begin{array}{l}-0.320^{*} \\
(0.173)\end{array}$ & $\begin{array}{c}-0.913 * * * \\
(0.290)\end{array}$ & $\begin{array}{l}-0.522 * \\
(0.308)\end{array}$ & $\begin{array}{l}-0.495 \\
(0.316)\end{array}$ & $\begin{array}{c}0.497 \\
(1.355)\end{array}$ & $\begin{array}{c}-0.519^{*} \\
(0.311)\end{array}$ & \\
\hline $\operatorname{Ln}($ Sales $)$ & $\begin{array}{c}0.056^{* * * *} \\
(0.006)\end{array}$ & $\begin{array}{c}0.047 * * * \\
(0.007)\end{array}$ & $\begin{array}{c}0.043 * * * \\
(0.007)\end{array}$ & $\begin{array}{c}0.011 \\
(0.028)\end{array}$ & $\begin{array}{c}0.046 * * * \\
(0.007)\end{array}$ & $\begin{array}{c}0.080 * * * \\
(0.013)\end{array}$ & $\begin{array}{c}0.061^{* * * *} \\
(0.013)\end{array}$ & $\begin{array}{c}0.061 * * * \\
(0.014)\end{array}$ & $\begin{array}{l}-0.029 \\
(0.057)\end{array}$ & $\begin{array}{c}0.060 * * * \\
(0.014)\end{array}$ & \\
\hline Tobin's Q & $\begin{array}{c}0.010 * * * \\
(0.002)\end{array}$ & $\begin{array}{c}0.010^{* * *} \\
(0.003)\end{array}$ & $\begin{array}{c}0.011^{* * *} \\
(0.003)\end{array}$ & $\begin{array}{l}-0.001 \\
(0.002)\end{array}$ & $\begin{array}{c}0.010 * * * \\
(0.003)\end{array}$ & $\begin{array}{c}0.019 * * * \\
(0.004)\end{array}$ & $\begin{array}{c}0.019 * * * \\
(0.005)\end{array}$ & $\begin{array}{c}0.021 * * * \\
(0.006)\end{array}$ & $\begin{array}{c}-0.003 \\
(0.005)\end{array}$ & $\begin{array}{c}0.018 * * * \\
(0.005)\end{array}$ & \\
\hline Product market HHI & $\begin{array}{c}0.469 * * * \\
(0.147)\end{array}$ & $\begin{array}{c}0.399 * * \\
(0.158)\end{array}$ & $\begin{array}{c}0.442 * * \\
(0.185)\end{array}$ & $\begin{array}{c}0.173 \\
(0.461)\end{array}$ & $\begin{array}{c}0.390^{* *} \\
(0.164)\end{array}$ & $\begin{array}{c}1.346^{* * *} \\
(0.273)\end{array}$ & $\begin{array}{c}1.197 * * * \\
(0.301)\end{array}$ & $\begin{array}{c}1.416^{* * *} \\
(0.350)\end{array}$ & $\begin{array}{c}0.743 \\
(0.899)\end{array}$ & $\begin{array}{c}1.165^{* * *} \\
(0.314)\end{array}$ & \\
\hline Product market $\mathrm{HHI}^{2}$ & $\begin{array}{c}-0.745^{*} \\
(0.415)\end{array}$ & $\begin{array}{l}-0.439 \\
(0.429)\end{array}$ & $\begin{array}{l}-0.578 \\
(0.521)\end{array}$ & $\begin{array}{c}0.066 \\
(1.006)\end{array}$ & $\begin{array}{l}-0.312 \\
(0.460)\end{array}$ & $\begin{array}{c}-2.593 * * * \\
(0.659)\end{array}$ & $\begin{array}{c}-1.937 * * * \\
(0.728)\end{array}$ & $\begin{array}{c}-3.143 * * * \\
(1.040)\end{array}$ & $\begin{array}{c}-0.833 \\
(1.859)\end{array}$ & $\begin{array}{c}-1.638^{* *} \\
(0.814)\end{array}$ & \\
\hline Coincident Index & $\begin{array}{l}-0.000 \\
(0.001)\end{array}$ & $\begin{array}{c}-0.008 * * * \\
(0.001)\end{array}$ & $\begin{array}{c}-0.008 * * * \\
(0.001)\end{array}$ & $\begin{array}{c}-0.020 * * \\
(0.008)\end{array}$ & $\begin{array}{c}-0.009 * * * \\
(0.001)\end{array}$ & $\begin{array}{l}0.003 * \\
(0.001)\end{array}$ & $\begin{array}{c}-0.015^{* * *} * \\
(0.002)\end{array}$ & $\begin{array}{c}-0.015 * * * \\
(0.002)\end{array}$ & $\begin{array}{c}-0.040 * * \\
(0.016)\end{array}$ & $\begin{array}{c}-0.015 * * * \\
(0.002)\end{array}$ & \\
\hline
\end{tabular}




\begin{tabular}{|c|c|c|c|c|c|c|c|c|c|c|c|}
\hline Venture Capital & $\begin{array}{c}0.004 * * * \\
(0.001)\end{array}$ & $\begin{array}{l}-0.001 \\
(0.001)\end{array}$ & $\begin{array}{l}-0.001 \\
(0.001)\end{array}$ & $\begin{array}{c}-0.008^{*} \\
(0.005)\end{array}$ & $\begin{array}{l}-0.001 \\
(0.001)\end{array}$ & $\begin{array}{c}0.009 * * * \\
(0.002)\end{array}$ & $\begin{array}{l}-0.002 \\
(0.002)\end{array}$ & $\begin{array}{l}-0.003 \\
(0.002)\end{array}$ & $\begin{array}{l}-0.002 \\
(0.009)\end{array}$ & $\begin{array}{l}-0.002 \\
(0.002)\end{array}$ & \\
\hline Other controls & & & & & & & & & & & Yes \\
\hline Industry Fixed Effect & Yes & Yes & Yes & Yes & Yes & Yes & Yes & Yes & Yes & Yes & Yes \\
\hline Year Fixed Effect & Yes & Yes & Yes & Yes & Yes & Yes & Yes & Yes & Yes & Yes & Yes \\
\hline Observations & 26,816 & 26,816 & 24,724 & 2,092 & 26,816 & 26,816 & 26,816 & 24,724 & 2,092 & 26,816 & 26,974 \\
\hline R-squared & 0.3563 & 0.2885 & 0.3007 & 0.1534 & 0.2814 & 0.3447 & 0.2453 & 0.2581 & 0.0616 & 0.2347 & 0.4418 \\
\hline$F$-statistic & $262.16 * * *$ & $240.40 * * *$ & $232.25 * * *$ & $11.63 * * *$ & $222.93 * * *$ & $423.68^{* * *}$ & $355.49 * * *$ & $347.24 * * *$ & $9.74 * * *$ & $325.17 * * *$ & $1518.21 * * *$ \\
\hline
\end{tabular}

Note: This table reports the results (standard errors in parentheses) specified by Eq. (1) (Model $1-3$ and $6-8$ ) and Eq. (6) (Model 5 and 10), where dependent variables are the number of patents and citations being filed by firms respectively. Models employed are pooled OLS with standard robustness errors (Models 1 and 6) and instrumented two-stage least squares (2SLS) (Models $2-5$ and 7 - 10). The instrument used is state median Tier 1 risk-based ratio. In specific, Model 3 and 8 report the estimations for the subsample firms that operate over larger geographical areas (Traded_firm f $\left._{i}=1\right)$. Model 4 and 9 show the estimations for the subsample firms whose markets are confined to a single banking market (Traded_firm ${ }_{i}=0$ ). All estimations control for industry and year fixed effects. All models include full set of control variables. The $*, * *$ and $* * *$ denote statistical significance at $10 \%, 5 \%$ and $1 \%$ level for which the null hypothesis is rejected. 
Table 3 The Impacts of State Banking Market Competition on the Nature and Risk of Corporate Innovation

\begin{tabular}{|c|c|c|c|c|c|c|c|c|}
\hline \multirow[t]{2}{*}{ Dependent variable } & \multicolumn{2}{|c|}{$\ln (\text { LowCites })_{i t}$} & \multicolumn{2}{|c|}{$\ln (\text { HighCites })_{i t}$} & \multicolumn{2}{|c|}{ Generality $_{i t}$} & \multicolumn{2}{|c|}{ originality $_{i t}$} \\
\hline & $(1)$ & $(2)$ & (3) & (4) & (5) & (6) & $(7)$ & $(8)$ \\
\hline$H_{j t}$ & $\begin{array}{c}1.241 * * * \\
(0.359)\end{array}$ & $\begin{array}{c}0.715^{* * *} \\
(0.050)\end{array}$ & $\begin{array}{c}1.040^{* * *} \\
(0.345)\end{array}$ & $\begin{array}{c}0.161 * * * \\
(0.042)\end{array}$ & $\begin{array}{c}0.348 * * * \\
(0.068)\end{array}$ & $\begin{array}{c}0.065 * * * \\
(0.009)\end{array}$ & $\begin{array}{l}-0.076 \\
(0.062)\end{array}$ & $\begin{array}{l}-0.013 \\
(0.009)\end{array}$ \\
\hline$H_{j t} \times$ Traded_firm ${ }_{i}$ & & $\begin{array}{c}-0.631 \text { *** } \\
(0.040)\end{array}$ & & $\begin{array}{c}-0.067 * * \\
(0.029)\end{array}$ & & $\begin{array}{c}-0.033^{* * *} \\
(0.007)\end{array}$ & & $\begin{array}{c}0.006 \\
(0.006)\end{array}$ \\
\hline Traded_firm $_{i}$ & & $\begin{array}{c}0.403 * * * \\
(0.025)\end{array}$ & & $\begin{array}{c}0.655^{* * * *} \\
(0.181)\end{array}$ & & $\begin{array}{c}0.190 * * * \\
(0.044)\end{array}$ & & $\begin{array}{l}-0.064 \\
(0.041)\end{array}$ \\
\hline Control variables & Yes & Yes & Yes & Yes & Yes & Yes & Yes & Yes \\
\hline Industry Fixed Effect & Yes & Yes & Yes & Yes & Yes & Yes & Yes & Yes \\
\hline Year Fixed Effect & Yes & Yes & Yes & Yes & Yes & Yes & Yes & Yes \\
\hline Observations & 5,032 & 5,032 & 6,794 & 6,794 & 13,324 & 13,324 & 13,324 & 13,324 \\
\hline R-squared & 0.3373 & 0.4050 & 0.2914 & 0.3150 & 0.2086 & 0.2547 & 0.0180 & 0.0208 \\
\hline$F$-statistic & $102.21 * * *$ & $91.88 * * *$ & $58.85^{* * *}$ & $56.18 * * *$ & $153.08 * * *$ & $159.42 * * *$ & $6.91 * * *$ & $6.74 * * *$ \\
\hline
\end{tabular}

Note: This table reports the results (standard errors in parentheses) specified by Eq. (1) (Model 1, 3, 5 and 7) and Eq. (6) (Model 2, 4, 6 and 8), where dependent variables are the underlying risks and nature of innovation. Specifically, $\ln (\text { LowCites })_{i t}\left(\ln (\text { LowCites })_{i t}\right)$ is the natural logarithm of one plus the total number of patents granted by companies in state $j$ in year $t$ that are in the top (bottom) quartile of year $t$ 's citation distribution. Generality $\left(\right.$ Originality $\left._{i t}\right)$ is an index measures the percentage of citations received (made) by a patent that belong to a wide range of technology fields. All specifications are estimated by employing instrumented two-stage least squares (2SLS). The instrument used is state median Tier 1 risk-based ratio. All estimations control for industry and year fixed effects. All models include full set of control variables and the results are available on request from the authors. $*, * *$ and $* * *$ denote statistical significance at $10 \%, 5 \%$ and $1 \%$ level respectively. 
Table 4 The Impacts of Regional Banking Market Competition on the Level of Corporate Innovation

\begin{tabular}{|c|c|c|c|c|c|c|c|}
\hline \multirow[t]{2}{*}{ Dependent variable } & \multicolumn{3}{|c|}{$\ln (\text { Patent })_{i t}$} & \multicolumn{3}{|c|}{$\ln (\text { Citation })_{i t}$} & \multirow{2}{*}{$\frac{\boldsymbol{R} \text { egion_H } \boldsymbol{r t}}{\text { First stage }}$} \\
\hline & $\begin{array}{c}\text { OLS } \\
(1)\end{array}$ & $\begin{array}{c}2 \text { SLS } \\
(2)\end{array}$ & $\begin{array}{c}2 \text { 2SLS } \\
\text { (3) }\end{array}$ & $\begin{array}{c}\text { OLS } \\
(4)\end{array}$ & $\begin{array}{c}\text { 2SLS } \\
(5)\end{array}$ & $\begin{array}{c}\text { 2SLS } \\
(6)\end{array}$ & \\
\hline Region_Tier 1 ration $_{r t}$ & & & & & & & $\begin{array}{c}-0.141 * * * \\
(0.016)\end{array}$ \\
\hline Region_H $H_{r t}$ & $\begin{array}{c}0.025 \\
(0.058)\end{array}$ & $\begin{array}{c}0.345 * * * \\
(0.080)\end{array}$ & $\begin{array}{c}0.311^{* * *} \\
(0.068)\end{array}$ & $\begin{array}{c}0.047 \\
(0.103)\end{array}$ & $\begin{array}{c}0.756^{* * *} \\
(0.150)\end{array}$ & $\begin{array}{c}0.727 * * * \\
(0.120)\end{array}$ & \\
\hline Region_H $H_{r t} \times$ Traded_firm ${ }_{i}$ & & & $\begin{array}{c}0.024 * * * \\
(0.009)\end{array}$ & & & $\begin{array}{c}0.045^{* *} \\
(0.018)\end{array}$ & \\
\hline Traded_firm $_{i}$ & & & $\begin{array}{c}0.054 \\
(0.056)\end{array}$ & & & $\begin{array}{c}0.049 \\
(0.108)\end{array}$ & \\
\hline Control variables & Yes & Yes & Yes & Yes & Yes & Yes & Yes \\
\hline Other controls & & & & & & & Yes \\
\hline Industry Fixed Effect & Yes & Yes & Yes & Yes & Yes & Yes & Yes \\
\hline Year Fixed Effect & Yes & Yes & Yes & Yes & Yes & Yes & Yes \\
\hline State Fixed Effect & Yes & Yes & Yes & Yes & Yes & Yes & Yes \\
\hline Observations & 26,491 & 26,491 & 26,816 & 26,491 & 26,491 & 26,816 & 26,496 \\
\hline R-squared & 0.3691 & 0.2924 & 0.3710 & 0.3556 & 0.2382 & 0.3572 & 0.8191 \\
\hline$F$-statistic & $119.02 * * *$ & $107.59 * * *$ & $118.69 * * *$ & $191.21 * * *$ & $155.81 * * *$ & $190.43 * * *$ & $3628.27 * * *$ \\
\hline
\end{tabular}

Note: This table reports the results (standard errors in parentheses) specified by Eq. (2) (Model $1-2$ and $4-5$ ) and Eq. (7) (Model 3 and 6), where dependent variables are the number of patents and citations being filed by firms respectively. Models employed are pooled OLS with standard robustness errors (Models 1 and 4) and instrumented two-stage least squares (2SLS) (Models $2-3$ and $5-6$ ). The instrument used is regional median Tier 1 riskbased ratio. All estimations control for industry, year and state fixed effects. All models include full set of control variables and the results are available on request from the authors. *,** and *** denote statistical significance at $10 \%, 5 \%$ and $1 \%$ level respectively. 
Table 5 The Impacts of Regional Banking Market Competition on the Nature and Risk of Corporate Innovation

\begin{tabular}{|c|c|c|c|c|c|c|c|c|}
\hline \multirow[t]{2}{*}{ Dependent variable } & \multicolumn{2}{|c|}{$\ln (\text { LowCites })_{i t}$} & \multicolumn{2}{|c|}{$\ln (\text { HighCites })_{i t}$} & \multicolumn{2}{|c|}{ Generality $_{i t}$} & \multicolumn{2}{|c|}{ Originality $_{i t}$} \\
\hline & $(1)$ & (2) & (3) & $(4)$ & $(5)$ & $(6)$ & $(7)$ & $(8)$ \\
\hline \multirow[t]{2}{*}{ Region_H $H_{r t}$} & 0.112 & 0.128 & -0.171 & -0.095 & $0.054 *$ & $0.056^{* *}$ & -0.052 & -0.047 \\
\hline & $(0.193)$ & $(0.170)$ & $(0.145)$ & $(0.130)$ & $(0.031)$ & $(0.026)$ & $(0.032)$ & $(0.029)$ \\
\hline \multirow{2}{*}{ Region_H $H_{r t} \times$ Traded_firm ${ }_{i}$} & & 0.015 & & -0.008 & & 0.004 & & -0.003 \\
\hline & & $(0.029)$ & & $(0.020)$ & & $(0.005)$ & & $(0.005)$ \\
\hline \multirow[t]{2}{*}{ Traded_firm $_{i}$} & & 0.245 & & $0.265^{* *}$ & & 0.013 & & -0.046 \\
\hline & & $(0.174)$ & & $(0.128)$ & & $(0.032)$ & & $(0.031)$ \\
\hline Control variables & Yes & Yes & Yes & Yes & Yes & Yes & Yes & Yes \\
\hline Industry Fixed Effect & Yes & Yes & Yes & Yes & Yes & Yes & Yes & Yes \\
\hline Year Fixed Effect & Yes & Yes & Yes & Yes & Yes & Yes & Yes & Yes \\
\hline State Fixed Effect & Yes & Yes & Yes & Yes & Yes & Yes & Yes & Yes \\
\hline Observations & 4,951 & 5,032 & 6,698 & 6,794 & 13,156 & 13,324 & 13,156 & 13,324 \\
\hline R-squared & 0.3986 & 0.4041 & 0.3200 & 0.3438 & 0.2302 & 0.2586 & 0.0301 & 0.0307 \\
\hline$F$-statistic & $89.57 * * *$ & $41.97 * * *$ & $89.39 * * *$ & $43.96^{* * *}$ & $69.60 * * *$ & $74.27 * * *$ & $4.88 * * *$ & $5.17 * * *$ \\
\hline
\end{tabular}

Note: This table reports the results (standard errors in parentheses) specified by Eq. (2) (Model 1, 3, 5 and 7) and Eq. (7) (Model 2, 4, 6 and 8), where dependent variables are the underlying risks and nature of innovation. Specifically, $\ln (\text { LowCites })_{i t}\left(\ln (\text { LowCites })_{i t}\right)$ is the natural logarithm of one plus the total number of patents granted by companies in state $j$ in year $t$ that are in the top (bottom) quartile of year $t$ 's citation distribution. Generality it $\left(\right.$ Originality $\left._{i t}\right)$ is an index measures the percentage of citations received (made) by a patent that belong to a wide range of technology fields. All specifications are estimated by employing instrumented two-stage least squares (2SLS). The instrument used is regional median Tier 1 risk-based ratio. All estimations control for industry, year and state fixed effects. All models include full set of control variables and the results are available on request from the authors. *,** and $* * *$ denote statistical significance at $10 \%, 5 \%$ and $1 \%$ level respectively. 
Table 6 The Impacts of Banking Market Competition in Neighboring States on the Level of Corporate Innovation

\begin{tabular}{|c|c|c|c|c|c|c|c|c|}
\hline Dependent variable & \multicolumn{4}{|c|}{$\ln (\text { Patent })_{i t}$} & \multicolumn{4}{|c|}{$\ln (\text { Citation })_{i t}$} \\
\hline Neigh_H $H_{j t} \times$ Traded_firm ${ }_{i}$ & & & & $\begin{array}{l}0.232 * \\
(0.141)\end{array}$ & & & & $\begin{array}{c}0.736 * * \\
(0.296)\end{array}$ \\
\hline Control vairables & Yes & Yes & Yes & Yes & Yes & Yes & Yes & Yes \\
\hline Industry Fixed Effect & Yes & Yes & Yes & Yes & Yes & Yes & Yes & Yes \\
\hline Year Fixed Effect & Yes & Yes & Yes & Yes & Yes & Yes & Yes & Yes \\
\hline State Fixed Effect & Yes & Yes & Yes & Yes & Yes & Yes & Yes & Yes \\
\hline
\end{tabular}

Note: This table reports the results (standard errors in parentheses) specified by Eq. (3) (Model $1-3$ and 5 - 7) and Eq. (8) (Model 4 and 8), where dependent variables are the number of patents and citations being filed by firms respectively. Neigh_H $H_{j t}$ is distance weighted average $H$ value for state j's all contiguous neighbors. Models employed are all pooled OLS with standard robustness errors. In specific, Model 2 and 6 report the estimations for the subsample firms that operate over larger geographical areas (Traded_firm ir $\left._{i}=1\right)$. Model 3 and 7 show the estimations for the subsample firms whose markets are confined to a single banking market (Traded_firm I $\left._{i}=0\right)$. All estimations control for industry, year and state fixed effects. All models include full set of control variables and the results are available on request from the authors. *, $* *$ and $* * *$ denote statistical significance at $10 \%, 5 \%$ and $1 \%$ level respectively. 
Table 7 The Impacts of Banking Market Competition in Neighboring States on the Nature and Risk of Corporate Innovation

\begin{tabular}{|c|c|c|c|c|c|c|c|c|}
\hline \multirow[t]{2}{*}{ Dependent variable } & \multicolumn{2}{|c|}{$\ln (\text { LowCites })_{i t}$} & \multicolumn{2}{|c|}{$\ln (\text { HighCites })_{i t}$} & \multicolumn{2}{|c|}{ Generality $_{i t}$} & \multicolumn{2}{|c|}{ originality $_{i t}$} \\
\hline & $(1)$ & (2) & (3) & (4) & $(5)$ & (6) & $(7)$ & $(8)$ \\
\hline \multirow[t]{2}{*}{ Neigh_H $H_{j t}$} & 0.138 & 0.183 & 0.088 & 0.108 & 0.011 & 0.006 & -0.028 & -0.014 \\
\hline & $(0.131)$ & $(0.641)$ & $(0.117)$ & $(0.090)$ & $(0.023)$ & $(0.023)$ & $(0.022)$ & $(0.021)$ \\
\hline \multirow{2}{*}{$N e i g h_{-} H_{j t} \times T r a d e d \_f i r m_{i}$} & & 0.223 & & 0.038 & & $0.040 *$ & & -0.004 \\
\hline & & $(0.629)$ & & $(0.072)$ & & $(0.022)$ & & $(0.020)$ \\
\hline \multirow{2}{*}{ Traded_firm $_{i}$} & & $0.202 *$ & & $0.167 *$ & & 0.027 & & 0.004 \\
\hline & & $(0.120)$ & & (0.094) & & $(0.025)$ & & $(0.023)$ \\
\hline Control variables & Yes & Yes & Yes & Yes & Yes & Yes & Yes & Yes \\
\hline Industry Fixed Effect & Yes & Yes & Yes & Yes & Yes & Yes & Yes & Yes \\
\hline Year Fixed Effect & Yes & Yes & Yes & Yes & Yes & Yes & Yes & Yes \\
\hline State Fixed Effect & Yes & Yes & Yes & Yes & Yes & Yes & Yes & Yes \\
\hline Observations & 5,032 & 5,032 & 6,794 & 6,794 & 13,324 & 13,324 & 13,324 & 13,324 \\
\hline R-squared & 0.4023 & 0.4048 & 0.3429 & 0.3444 & 0.2584 & 0.2586 & 0.0302 & 0.0305 \\
\hline$F$-statistic & $42.73 * * *$ & $42.10 * * *$ & $44.92 * * *$ & $44.07 * * *$ & $75.99 * * *$ & $56.32 * * *$ & $5.14 * * *$ & $5.09 * * *$ \\
\hline
\end{tabular}

Note: This table reports the results (standard errors in parentheses) specified by Eq. (3) (Model 1, 3, 5 and 7) and Eq. (8) (Model 2, 4, 6 and 8), where dependent variables are the underlying risks and nature of innovation. Specifically, $\ln (\text { LowCites })_{i t}\left(\ln (\text { LowCites) })_{\text {it }}\right.$ ) is the natural logarithm of one plus the total number of patents granted by companies in state $j$ in year $t$ that are in the top (bottom) quartile of year $t$ 's citation distribution. Generality ${ }_{i t}\left(\right.$ Originality $_{i t}$ ) is an index measures the percentage of citations received (made) by a patent that belong to a wide range of technology fields. $N e i g h \_H_{j t}$ is distance weighted average $H$ value for state j's all contiguous neighbors. All specifications are estimated by employing pooled OLS with standard robustness errors. All models include full set of control variables and the results are available on request from the authors. *** and $* * *$ denote statistical significance at $10 \%, 5 \%$ and $1 \%$ level respectively. 


\begin{tabular}{|c|c|c|c|c|c|c|c|c|}
\hline \multirow{2}{*}{$\begin{array}{l}\text { Panel A } \\
H H I_{j t}\end{array}$} & \multicolumn{2}{|c|}{$\ln (\text { Patent })_{i t}$} & \multicolumn{2}{|c|}{$\ln (\text { Citation })_{i t}$} & \multirow{2}{*}{$\begin{array}{c}\boldsymbol{\operatorname { l n } ( \text { LowCites } ) _ { i t }} \\
-0.816^{* * * *} \\
(0.236)\end{array}$} & \multirow{2}{*}{$\begin{array}{c}\ln (\text { HighCites })_{i t} \\
-0.680^{* * *} \\
(0.234)\end{array}$} & \multirow{2}{*}{$\begin{array}{c}\text { Generality }_{\boldsymbol{i t}} \\
-0.245^{* * *} \\
(0.090)\end{array}$} & \multirow{2}{*}{$\begin{array}{c}\text { Originality }_{\text {it }} \\
0.057 \\
(0.083)\end{array}$} \\
\hline & $\begin{array}{c}-1.197 * * * \\
(0.129)\end{array}$ & $\begin{array}{c}-1.354 * * * \\
(0.132)\end{array}$ & $\begin{array}{l}-2.692 * * * \\
(0.227)\end{array}$ & $\begin{array}{c}-2.890 * * * \\
(0.231)\end{array}$ & & & & \\
\hline $\mathrm{HHI}_{j t} \times$ Traded_firm $_{i}$ & & $\begin{array}{c}0.222 * * * \\
(0.028)\end{array}$ & & $\begin{array}{c}0.234 * * * \\
(0.052)\end{array}$ & $\begin{array}{c}0.217 * * * \\
(0.068)\end{array}$ & $\begin{array}{r}0.142 * * \\
(0.060)\end{array}$ & $\begin{array}{c}0.019 \\
(0.806)\end{array}$ & $\begin{array}{l}-0.051 \\
(0.743)\end{array}$ \\
\hline Traded_firm $i$ & & $\begin{array}{c}0.026 \\
(0.031) \\
\end{array}$ & & $\begin{array}{c}0.137 * * \\
(0.061) \\
\end{array}$ & $\begin{array}{l}0.186 * * \\
(0.085) \\
\end{array}$ & $\begin{array}{l}0.167 * * \\
(0.081)\end{array}$ & $\begin{array}{l}-0.007 \\
(0.076)\end{array}$ & $\begin{array}{l}-0.023 \\
(0.069)\end{array}$ \\
\hline Control variables & Yes & Yes & Yes & Yes & Yes & Yes & Yes & Yes \\
\hline Industry Fixed Effect & Yes & Yes & Yes & Yes & Yes & Yes & Yes & Yes \\
\hline Year Fixed Effect & Yes & Yes & Yes & Yes & Yes & Yes & Yes & Yes \\
\hline Observations & 26,816 & 26,816 & 26,816 & 26,816 & 5,032 & 6,794 & 13,324 & 13,324 \\
\hline R-squared & 0.3584 & 0.3607 & 0.3479 & 0.3493 & 0.3767 & 0.3151 & 0.2530 & 0.0207 \\
\hline$F$-statistic & $263.44 * * *$ & $253.62 * * *$ & $427.22 * * *$ & $410.12 * * *$ & $81.59 * * *$ & $56.26 * * *$ & $156.85^{* * *}$ & $6.72 * * *$ \\
\hline \multicolumn{9}{|l|}{ Panel B } \\
\hline Neigh_HHI $I_{j t}$ & $\begin{array}{c}-0.448 * * \\
(0.197)\end{array}$ & $\begin{array}{l}-0.226 \\
(0.203)\end{array}$ & $\begin{array}{l}-0.636^{*} \\
(0.378)\end{array}$ & $\begin{array}{l}-0.286 \\
(0.388)\end{array}$ & $\begin{array}{l}-0.486 \\
(0.979)\end{array}$ & $\begin{array}{l}-0.122 \\
(0.606)\end{array}$ & $\begin{array}{l}-0.010 \\
(0.050)\end{array}$ & $\begin{array}{c}0.012 \\
(0.105)\end{array}$ \\
\hline Neigh_HHI $I_{j t} \times$ Traded_firm ${ }_{i}$ & & $\begin{array}{c}-0.584 * * * \\
(0.137)\end{array}$ & & $\begin{array}{c}-0.795^{* * *} \\
(0.240)\end{array}$ & $\begin{array}{l}-0.782 \\
(0.969)\end{array}$ & $\begin{array}{l}-0.082 \\
(0.053)\end{array}$ & $\begin{array}{c}-0.037 * * \\
(0.016)\end{array}$ & $\begin{array}{c}0.032 \\
(0.041)\end{array}$ \\
\hline Traded_firm $i$ & & $\begin{array}{c}0.222 * * * \\
(0.029)\end{array}$ & & $\begin{array}{c}0.327 * * * \\
(0.057)\end{array}$ & $\begin{array}{c}0.436 * * * \\
(0.113) \\
\end{array}$ & $\begin{array}{l}0.180 * * \\
(0.084)\end{array}$ & $\begin{array}{c}0.012 \\
(0.021)\end{array}$ & $\begin{array}{l}-0.017 \\
(0.021)\end{array}$ \\
\hline Control variables & Yes & Yes & Yes & Yes & Yes & Yes & Yes & Yes \\
\hline Industry Fixed Effect & Yes & Yes & Yes & Yes & Yes & Yes & Yes & Yes \\
\hline Year Fixed Effect & Yes & Yes & Yes & Yes & Yes & Yes & Yes & Yes \\
\hline State Fixed Effect & Yes & Yes & Yes & Yes & Yes & Yes & Yes & Yes \\
\hline Observations & 23,374 & 23,374 & 23,374 & 23,374 & 4,103 & 5,799 & 11,505 & 11,505 \\
\hline R-squared & 0.3799 & 0.3712 & 0.3630 & 0.3639 & 0.4072 & 0.3053 & 0.2475 & 0.027 \\
\hline$F$-statistic & $109.11 * * *$ & $106.78 * * *$ & $181.94 * * *$ & $177.84 * * *$ & $35.91 * * *$ & $38.46 * * *$ & $68.75^{* * *}$ & $4.77 * * *$ \\
\hline
\end{tabular}

Note: This table reports the results (standard errors in parentheses) for robustness tests employing Herfindahl-Hirschman Index (HHI) as the alternative proxy for measuring the level of banking market competition. The dependent variables are the natural logarithm of one plus the total number of patent and citations, patents in the bottom and top quartile of citation distributions, and the percentage of citations received (made) by a patent that belong to a wide range of technology fields respectively. Models employed are instrumented two-stage least squares. The instrument used is state median Tier 1 risk-based ratio. All estimations control for industry and year fixed effects. All models include full set of control variables and the results are available on request from the authors. *,** and *** denote statistical significance at $10 \%, 5 \%$ and $1 \%$ level respectively. 
Table 9 Robustness Tests for the Impacts of Banking Market Competition on the Level of Corporate Innovation between 1997 and 2004

\begin{tabular}{|c|c|c|c|c|c|c|c|c|c|c|c|c|}
\hline \multirow{3}{*}{ Dependent variable } & \multicolumn{4}{|c|}{ Home-state Banking Market Competition } & \multicolumn{4}{|c|}{ Neighbor-state Banking Market Competition } & \multicolumn{4}{|c|}{ Regional Banking Market Competition } \\
\hline & \multicolumn{2}{|c|}{$\ln (\text { Patent })_{i t}$} & \multicolumn{2}{|c|}{$\ln (\text { Citation })_{i t}$} & \multicolumn{2}{|c|}{$\ln (\text { Patent })_{i t}$} & \multicolumn{2}{|c|}{$\ln (\text { Citation })_{i t}$} & \multicolumn{2}{|c|}{$\ln (\text { Patent })_{i t}$} & \multicolumn{2}{|c|}{$\ln (\text { Citation })_{i t}$} \\
\hline & $(1)$ & $(2)$ & $(3)$ & $(4)$ & $(5)$ & $(6)$ & $(7)$ & $(8)$ & $(9)$ & $(10)$ & $(11)$ & $(12)$ \\
\hline Tier 1 ratio $_{i t}$ & $0.744 * * *$ & $1.292 * * *$ & $2.145^{* * *}$ & $4.275 * * *$ & & & & & & & & \\
\hline$H_{j t}$ & & -0.576 & & $-2.252 * *$ & & & & & & & & \\
\hline$H_{j t} \times$ Traded_firm ${ }_{i}$ & & 0.500 & & $1.591 * *$ & & & & & & & & \\
\hline Traded_firm ${ }_{i}$ & & & & & $0.308 * * *$ & $-0.206^{* *}$ & $0.650 * * *$ & 0.093 & & & & \\
\hline Neigh_H & & & & & & $0.559 * * *$ & & $0.849 * * *$ & & & & \\
\hline Traded_firm $_{i}$ & & & & & & $0.240 * * *$ & & $0.336 * * *$ & & & & \\
\hline Region_H $H_{r t}$ & & & & & & & & & $0.369 * * *$ & $0.366^{* * *}$ & $0.761 * * *$ & $0.747 * * *$ \\
\hline Region_H $H_{r t}$ & & & & & & & & & & $0.045 * * *$ & & $0.074 * * *$ \\
\hline Traded_firm $_{i}$ & & & & & & & & & & -0.108 & & -0.210 \\
\hline Control variables & Yes & Yes & Yes & Yes & Yes & Yes & Yes & Yes & Yes & Yes & Yes & Yes \\
\hline Industry Fixed Effect & Yes & Yes & Yes & Yes & Yes & Yes & Yes & Yes & Yes & Yes & Yes & Yes \\
\hline Year Fixed Effect & Yes & Yes & Yes & Yes & Yes & Yes & Yes & Yes & Yes & Yes & Yes & Yes \\
\hline State Fixed Effect & & & & & Yes & Yes & Yes & Yes & Yes & Yes & Yes & Yes \\
\hline Observations & 15,104 & 15,104 & 15,104 & 15,104 & 15,104 & 15,104 & 15,104 & 15,104 & 15,104 & 15,104 & 15,104 & 15,104 \\
\hline R-squared & 0.3468 & 0.345 & 0.351 & 0.344 & 0.3689 & 0.3706 & 0.3861 & 0.3948 & 0.3675 & 0.3690 & 0.3844 & 0.3854 \\
\hline$F$-statistic & $175.10 * * *$ & $161.8^{* * *}$ & $312.2 * * *$ & $281.8 * * *$ & $72.44 * * *$ & $71.30 * * *$ & $133.00 * * *$ & $134.99 * * *$ & $72.56^{* * *}$ & $71.41 * * *$ & $133.08 * * *$ & $130.77 * * *$ \\
\hline
\end{tabular}

Note: This table reports the results (standard errors in parentheses) for robustness tests for all specifications by restricting sample between 1997 and 2004, where dependent variables are the number of patents and citations being filed by firms respectively. Model $1-4$ measures the impacts of home state banking market competition by employing instrumented two-stage least squares (2SLS). The instrument used is state median Tier 1 risk-based ratio. Model 5 - 8 display the effects of banking competition in neighboring state by using pooled OLS with standard robustness errors. Neigh_H $H_{j t}$ is distance weighted average $H$ value for state j's all contiguous neighbors. Model $9-12$ estimate regional banking market effects. The models employed are instrumented two-stage least squares (2SLS) by using regional median Tier 1 risk-based ratio as the instrument. All estimations of neighboring and regional effects control for industry, year and state fixed effects, while the models of state effects only include industry and year fixed effects because $H$ is derived from state-specific reduced-form revenue equation. All models include full set of control variables and the results are available on request from the authors. $*, * *$ and $* * *$ denote statistical significance at $10 \%, 5 \%$ and $1 \%$ level respectively. 
Table 10 Comparisons between Local and Traded Firms

Panel A: Corporate Innovation Measures

\begin{tabular}{|c|c|c|c|c|c|c|c|c|c|c|c|c|}
\hline & \multicolumn{6}{|c|}{ Relative lower local banking competition } & \multicolumn{6}{|c|}{ Relative higher local banking competition } \\
\hline & \multicolumn{2}{|c|}{ local firms } & \multicolumn{2}{|c|}{ traded firms } & \multirow[b]{2}{*}{ Difference } & \multirow[b]{2}{*}{$t$-statistic } & \multicolumn{2}{|c|}{ local firms } & \multicolumn{2}{|c|}{ traded firms } & \multirow[b]{2}{*}{ Difference } & \multirow[b]{2}{*}{$t$-statistic } \\
\hline & $\operatorname{Mean}_{1}$ & $\delta_{1}$ & $\mathrm{Mean}_{2}$ & $\delta_{2}$ & & & $\mathrm{Mean}_{3}$ & $\delta_{3}$ & $\mathrm{Mean}_{4}$ & $\delta_{4}$ & & \\
\hline Number of patents & 4.249 & 1.024 & 11.279 & 0.689 & 7.030 & $3.1874^{* * *}$ & 7.878 & 2.109 & 11.043 & 0.621 & 3.165 & 1.4914 \\
\hline Number of citations & 54.470 & 10.682 & 137.598 & 7.708 & 83.127 & $3.3739^{* * * *}$ & 90.459 & 25.164 & 152.285 & 8.598 & 61.826 & $2.1282^{* *}$ \\
\hline 1st quartile cited patents & 6.269 & 1.123 & 11.829 & 0.873 & 5.561 & $1.5928^{*}$ & 12.308 & 2.962 & 10.639 & 0.575 & -1.669 & -0.6174 \\
\hline 4th quartile cited patents & 12.574 & 3.477 & 8.786 & 0.483 & -3.787 & $-1.6490^{*}$ & 7.791 & 2.150 & 10.041 & 0.518 & 2.250 & 0.9902 \\
\hline
\end{tabular}

Panel B: Key Firm Characteristics

\begin{tabular}{|c|c|c|c|c|c|c|c|c|c|c|}
\hline & \multicolumn{4}{|c|}{ Relative lower local bank competition } & \multicolumn{4}{|c|}{ Relative higher local bank competition } & \multirow[b]{3}{*}{$\begin{array}{l}\text { Difference-in- } \\
\text { Differences }\end{array}$} & \multirow[b]{3}{*}{$t$-statistic } \\
\hline & \multicolumn{2}{|c|}{ local firms } & \multicolumn{2}{|c|}{ traded firms } & \multicolumn{2}{|c|}{ local firms } & \multicolumn{2}{|c|}{ traded firms } & & \\
\hline & Mean $_{1}$ & $\delta_{1}$ & $\mathrm{Mean}_{2}$ & $\delta_{2}$ & Mean $_{1}$ & $\delta_{1}$ & $\mathrm{Mean}_{2}$ & $\delta_{2}$ & & \\
\hline Size & 6.073 & 3.049 & 5.085 & 2.558 & 6.064 & 3.051 & 5.122 & 2.504 & 0.046 & 1.6684 \\
\hline Age & 2.493 & 1.040 & 2.366 & 1.056 & 2.457 & 1.053 & 2.303 & 1.035 & -0.027 & $-1.6940^{*}$ \\
\hline ROA & -0.047 & 1.409 & -0.084 & 1.397 & -0.032 & 0.539 & -0.137 & 2.169 & 0.068 & 0.8598 \\
\hline Cash holding & 0.159 & 0.222 & 0.226 & 0.256 & 0.166 & 0.234 & 0.242 & 0.264 & 0.009 & 0.1710 \\
\hline Asset tangibility & 0.300 & 0.249 & 0.236 & 0.183 & 0.299 & 0.249 & 0.234 & 0.189 & -0.001 & -0.0929 \\
\hline Capital to labour ratio & 4.259 & 1.340 & 4.305 & 1.034 & 4.268 & 1.253 & 4.352 & 1.019 & 0.038 & $1.8861^{*}$ \\
\hline Leverage & 0.017 & 0.052 & 0.011 & 0.038 & 0.016 & 0.046 & 0.009 & 0.039 & -0.001 & -0.2542 \\
\hline Sales & 5205.68 & 16278.2 & 2306.41 & 9934.121 & 6080.37 & 17514.77 & 2162.31 & 9350.70 & -1018.79 & 0.5231 \\
\hline Tobin's Q & 0.811 & 5.727 & 1.253 & 10.642 & 1.109 & 6.118 & 1.491 & 7.206 & -0.06 & $1.6951^{*}$ \\
\hline Product market HHI & 0.039 & 0.064 & 0.012 & 0.011 & 0.046 & 0.069 & 0.012 & 0.011 & -0.007 & 1.0636 \\
\hline
\end{tabular}

Note: The table presents the mean and standard deviation of four corporate innovation measures (Panel A) and key firms' characteristic (Panel B) for the observations pertaining to each of the four subgroups and the t-test on the null hypothesis that the measured characteristics between local and traded firms are equality of means. The subsamples comprise firms headquartered in states with state-year $H$ below or above spatial lagged neighbouring $H$, and firms that operate within a single banking market if they compete in a local industry or across various banking markets if they compete in traded industries. The last two columns in Panel B show the two-sided t-test of the hypothesis that the variation of firm characteristics between competitively and less-competitively local banking market for both firm groups follows a parallel trend (i.e. the mean difference for columns $([1]-[3])-([2]-[4])$ equals zero). The ${ }^{*},{ }^{* *}$ and ${ }^{* * *}$ denote statistical significance at $10 \%, 5 \%$ and $1 \%$ level for which the null hypothesis is rejected. 
Table 11 Additional Tests for the Impacts of State Banking Market Competition on the Level of Corporate Innovation: The Role of Information

\begin{tabular}{|c|c|c|c|c|c|c|c|c|}
\hline Dependent variable & \multicolumn{4}{|c|}{$\ln (\text { Patent })_{i t}$} & \multicolumn{4}{|c|}{$\ln (\text { Citation })_{i t}$} \\
\hline \multicolumn{9}{|c|}{ Panel A: Kaplan_Zingales Index } \\
\hline & \multicolumn{2}{|c|}{ Low } & \multicolumn{2}{|c|}{ High } & \multicolumn{2}{|c|}{ Low } & \multicolumn{2}{|c|}{ High } \\
\hline & (1) & (2) & (3) & (4) & (5) & (6) & (7) & (8) \\
\hline$H_{j t}$ & $\begin{array}{c}1.385 * * * \\
(0.211)\end{array}$ & $\begin{array}{c}2.761 * * * \\
(0.730)\end{array}$ & $\begin{array}{c}2.787 * * * \\
(0.461)\end{array}$ & $\begin{array}{c}4.029 * * * \\
(1.106)\end{array}$ & $\begin{array}{c}3.249 * * * \\
(0.379)\end{array}$ & $\begin{array}{c}6.124 * * * \\
(1.536)\end{array}$ & $\begin{array}{c}5.921 * * * \\
(0.839)\end{array}$ & $\begin{array}{c}8.220 * * * \\
(2.115)\end{array}$ \\
\hline $\begin{array}{l}H_{j t} \\
\times \text { Traded_firm }\end{array}$ & & $\begin{array}{c}-1.435 * * \\
(0.715)\end{array}$ & & $\begin{array}{l}-1.334 \\
(0.990)\end{array}$ & & $\begin{array}{c}-3.011 * * \\
(1.511)\end{array}$ & & $\begin{array}{l}-2.459 \\
(1.900)\end{array}$ \\
\hline Traded_firm $_{i}$ & & $\begin{array}{l}1.044 * * \\
(0.425)\end{array}$ & & $\begin{array}{c}0.908 \\
(0.581)\end{array}$ & & $\begin{array}{c}2.048 * * \\
(0.894)\end{array}$ & & $\begin{array}{c}1.638 \\
(1.115)\end{array}$ \\
\hline Control variables & Yes & Yes & Yes & Yes & Yes & Yes & Yes & Yes \\
\hline Industry Fixed Effect & Yes & Yes & Yes & Yes & Yes & Yes & Yes & Yes \\
\hline Year Fixed Effect & Yes & Yes & Yes & Yes & Yes & Yes & Yes & Yes \\
\hline Observations & 15,744 & 15,744 & 11,072 & 11,072 & 15,744 & 15,744 & 11,072 & 11,072 \\
\hline R-squared & 0.5907 & 0.5866 & 0.4454 & 0.4360 & 0.6598 & 0.6550 & 0.5218 & 0.5135 \\
\hline$F$-statistic & $170.36^{* * *}$ & $158.11 * * *$ & $80.82 * * *$ & $73.92 * * *$ & $262.06 * * *$ & $240.18 * * *$ & $104.70^{* * *}$ & $94.91 * * *$ \\
\hline
\end{tabular}

Panel B: Patent Types Distribution

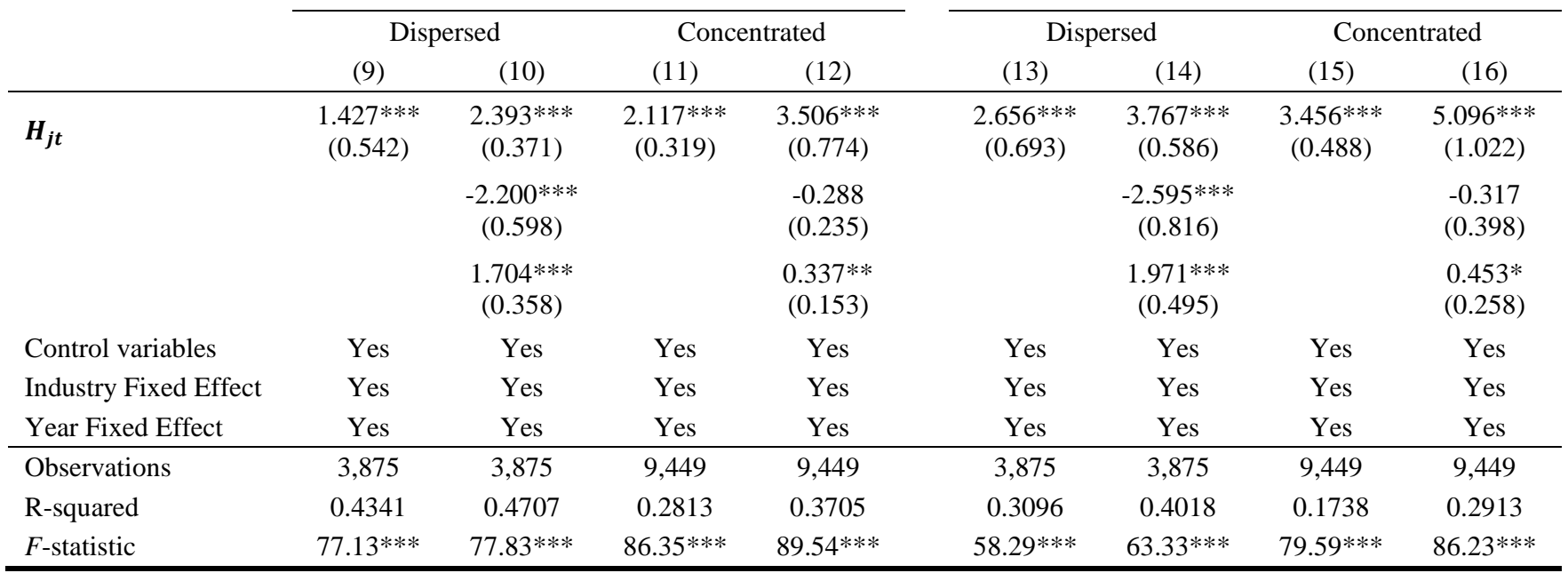

Note: This table reports the results (standard errors in parentheses) for additional tests for Eq. (6) explaining the heterogeneous treatment effects of own-state banking market competition. The dependent variables are the natural logarithm of one plus the total number of patent. Panel A (Model 1 - 8) examines firms' financial constraints by using Kaplan-Zingales (1997) Index. The 'High' ('Low') subsamples comprise firms with the index above (below) the across-industry median values, and we consider firms in the 'High' subsamples to be financially constrained. Panel B (Model 9-16) tests the characteristics of patent types distribution, in which the sample firms with higher (lower) kurtosis of the empirical distribution of patents among 6 different categories than 3 in year $t$ are defined to be 'Concentrated' ('Dispersed'). All specifications are estimated by employing instrumented two-stage least squares (2SLS). The instrument used is state median Tier 1 risk-based ratio. And all estimations in the table include industry and year fixed effects. All models include full set of control variables and the results are available on request from the authors. * $* *$ and $* * *$ denote statistical significance at $10 \%, 5 \%$ and $1 \%$ level respectively. 
Table 12 Additional Tests for the Impacts of Banking Market Competition in Neighboring States on the Level of Corporate Innovation: The Role of Information

\begin{tabular}{|c|c|c|c|c|c|c|c|c|}
\hline Dependent variable & \multicolumn{4}{|c|}{$\ln (\text { Patent })_{i t}$} & \multicolumn{4}{|c|}{$\ln (\text { Citation })_{i t}$} \\
\hline \multicolumn{9}{|c|}{ Panel A: Kaplan_Zingales Index } \\
\hline & \multicolumn{2}{|c|}{ Low } & \multicolumn{2}{|c|}{ High } & \multicolumn{2}{|c|}{ Low } & \multicolumn{2}{|c|}{ High } \\
\hline & (1) & (2) & (3) & (4) & (5) & (6) & (7) & $(8)$ \\
\hline$N e i g h \_H_{j t}$ & $\begin{array}{c}0.239 * * * \\
(0.043)\end{array}$ & $\begin{array}{c}0.161 * * * \\
(0.043)\end{array}$ & $\begin{array}{c}0.017 \\
(0.038)\end{array}$ & $\begin{array}{l}-0.015 \\
(0.039)\end{array}$ & $\begin{array}{c}0.489 * * * \\
(0.076)\end{array}$ & $\begin{array}{c}0.254 \\
(0.213)\end{array}$ & $\begin{array}{l}0.129 * \\
(0.074)\end{array}$ & $\begin{array}{c}0.047 \\
(0.075)\end{array}$ \\
\hline $\begin{array}{l}\text { Neigh_H }{ }_{j t} \\
\times \text { Traded_firm }\end{array}$ & & $\begin{array}{c}0.653 * * * \\
(0.080)\end{array}$ & & $\begin{array}{l}0.284 * * * \\
(0.052)\end{array}$ & & $\begin{array}{c}0.735 * * * \\
(0.101)\end{array}$ & & $\begin{array}{c}0.255 \\
(0.213)\end{array}$ \\
\hline Traded_firm $_{i}$ & & $\begin{array}{c}0.214 * * * \\
(0.063)\end{array}$ & & $\begin{array}{l}-0.020 \\
(0.069)\end{array}$ & & $\begin{array}{c}0.153 \\
(0.157)\end{array}$ & & $\begin{array}{l}-0.212 \\
(0.142)\end{array}$ \\
\hline Control variables & Yes & Yes & Yes & Yes & Yes & Yes & Yes & Yes \\
\hline Industry Fixed Effect & Yes & Yes & Yes & Yes & Yes & Yes & Yes & Yes \\
\hline Year Fixed Effect & Yes & Yes & Yes & Yes & Yes & Yes & Yes & Yes \\
\hline State Fixed Effect & Yes & Yes & Yes & Yes & Yes & Yes & Yes & Yes \\
\hline Observations & 15,744 & 15,744 & 11,072 & 11,072 & 15,744 & 15,744 & 11,072 & 11,072 \\
\hline R-squared & 0.4179 & 0.4217 & 0.3090 & 0.3509 & 0.4028 & 0.4036 & 0.2993 & 0.3276 \\
\hline$F$-statistic & $138.82 * * *$ & $137.59 * * *$ & $74.49 * * *$ & $73.35 * * *$ & $130.41 * * *$ & $127.68 * * *$ & $67.33 * * *$ & $66.10^{* * *}$ \\
\hline
\end{tabular}

Panel B: Patent Types Distribution

\begin{tabular}{|c|c|c|c|c|c|c|c|c|}
\hline & \multicolumn{2}{|c|}{ Dispersed } & \multicolumn{2}{|c|}{ Concentrated } & \multicolumn{2}{|c|}{ Dispersed } & \multicolumn{2}{|c|}{ Concentrated } \\
\hline & (9) & (10) & (11) & (12) & (13) & (14) & (15) & (16) \\
\hline$N e i g h \_H_{j t}$ & $\begin{array}{l}0.169 * \\
(0.095)\end{array}$ & $\begin{array}{c}0.093 \\
(0.096)\end{array}$ & $\begin{array}{c}0.055 \\
(0.035)\end{array}$ & $\begin{array}{c}0.041 \\
(0.035)\end{array}$ & $\begin{array}{c}0.570 * * * \\
(0.193)\end{array}$ & $\begin{array}{c}0.023 \\
(0.124)\end{array}$ & $\begin{array}{c}0.272 * * * \\
(0.079)\end{array}$ & $\begin{array}{c}0.020 \\
(0.062)\end{array}$ \\
\hline $\begin{array}{l}\text { Neigh_H } H_{j t} \\
\times \text { Traded_firm } \\
\end{array}$ & & $\begin{array}{c}0.593 * * * \\
(0.163)\end{array}$ & & $\begin{array}{c}0.106^{* *} \\
(0.049)\end{array}$ & & $\begin{array}{c}0.649 * * * \\
(0.199)\end{array}$ & & $\begin{array}{c}0.266^{* * * *} \\
(0.083)\end{array}$ \\
\hline Traded_firm $_{i}$ & & $\begin{array}{c}-0.021 \\
(0.158)\end{array}$ & & $\begin{array}{l}0.119 * \\
(0.068)\end{array}$ & & $\begin{array}{c}-0.088 \\
(0.208)\end{array}$ & & $\begin{array}{c}0.128 \\
(0.123)\end{array}$ \\
\hline Control variables & Yes & Yes & Yes & Yes & Yes & Yes & Yes & Yes \\
\hline Industry Fixed Effect & Yes & Yes & Yes & Yes & Yes & Yes & Yes & Yes \\
\hline Year Fixed Effect & Yes & Yes & Yes & Yes & Yes & Yes & Yes & Yes \\
\hline State Fixed Effect & Yes & Yes & Yes & Yes & Yes & Yes & Yes & Yes \\
\hline Observations & 3,875 & 3,875 & 9,449 & 9,449 & 3,875 & 3,875 & 9,449 & 9,449 \\
\hline R-squared & 0.5038 & 0.5069 & 0.3248 & 0.3945 & 0.4337 & 0.4348 & 0.2607 & 0.3116 \\
\hline$F$-statistic & $49.40 * * *$ & $48.76 * * *$ & $75.71 * * *$ & $74.42 * * *$ & $37.27 * * *$ & $36.49 * * *$ & $52.76^{* * *}$ & $51.69 * * *$ \\
\hline
\end{tabular}

Note: This table reports the results (standard errors in parentheses) for additional tests for Eq. (8) explaining the heterogeneous treatment effects of out-of-state banking market competition. The dependent variables are the natural logarithm of one plus the total number of patent. Panel A (Model 1 - 8) examines firms' financial constraints by using Kaplan-Zingales (1997) Index. The 'High' ('Low') subsamples comprise firms with the index above (below) the across-industry median values, and we consider firms in the 'High' subsamples to be financially constrained. Panel B (Model $9-16$ ) tests the characteristics of patent types distribution, in which the sample firms with higher (lower) kurtosis of the empirical distribution of patents among 6 different categories than 3 in year $t$ are defined to be 'Concentrated' ('Dispersed'). All specifications are estimated by employing pooled OLS with standard robustness errors. And all estimations in the table include industry, year and state fixed effects. All models include full set of control variables and the results are available on request from the authors. *, $* *$ and $* * *$ denote statistical significance at $10 \%, 5 \%$ and $1 \%$ level respectively. 